\title{
How Do Auditors Perceive Excess Cash Holdings? Evidence from Foreign Incorporated Firms
}

\author{
Deborah Smith \\ Cleveland State University \\ Yezen Kannan \\ Zayed University \\ Kimberly C. Gleason \\ American University of Sharjah
}

\begin{abstract}
Auditors face greater liability in some countries than others due to the nature of the institutional monitoring framework of legal claims that can potentially be brought against the auditor. This paper is the first to document the relationship between auditor liability and auditor pricing of excess cash holdings for clients across national borders, using a sample of foreign incorporated firms traded in the US. Our findings indicate that auditors demand a fee premium for foreign incorporated clients with greater excess cash holdings, consistent with that auditors recognizing the potential for legal exposure to agency conflict arising from foreign listed US traded clients. Furthermore, we examine aspects of foreign capital market protections, such as disclosure requirements, the strength of legal enforcement, and the strength of shareholder rights to better understand auditor perception of the liability they incur due to the agency costs associated with excess cash holdings. We find that there is a positive association between audit fees and excess cash holdings for firms where the country of incorporation permits greater liability of auditors in criminal and civil litigation. In addition, auditors assign higher audit fees to firms holding greater excess cash incorporated in countries with greater required accounting disclosure and stronger legal enforcement.
\end{abstract}

Keywords: Auditor liability, excess cash, agency theory, audit fees, international accounting 


\section{How Do Auditors Perceive Excess Cash Holdings? Evidence from Foreign Incorporated Firms}

\section{Introduction}

In this paper, we assess whether factors reflecting institutional quality augment the agency costs of excess cash holdings for a sample of foreign incorporated firms traded on United States stock exchanges, and whether these liability factors are reflected in the audit fees of these clients. Prior literature documents increased audit and business risk associated with country-level factors such as investor rights, legal protection, and disclosure (Bronson, Ghosh, and Hogan, 2018). While previous studies have investigated firm-level agency effects of excess cash, we are unaware of research addressing the effect of country-level governance risk on excess cash levels. Although there are now more than 800 foreign incorporated firms listed on the NYSE and NASDAQ-AMEX, to date there is a scarcity of literature that examines auditor pricing of excess cash holdings across countries and institutional regimes. This study is particularly relevant as businesses increase international operations, because the risk priced by auditors yields an agency cost to shareholders.

This study sheds further light on two streams of research: agency costs associated with excess cash holdings and auditor perceptions of business engagement risk. Following Dittmar and Mahrt-Smith (2007), our measure for excess cash holdings is determined using a regression predicting optimal cash levels. From the predicted optimal cash levels, we calculate the firm's excess cash holdings. We combine excess cash with auditor liability generated through institutional factors that characterize a firm's country of incorporation: accountant liability to claims in civil and criminal court, the extent of accounting disclosure requirements, the extent of legal enforcement, and the strength of shareholders' rights. 
Prior research indicates that the value of liquid assets is discounted in countries with weak investor protection, because incentives to tunnel are high and the risk of prosecution is low (Pinkowitz, Stultz, and Williamson, 2006). For cash in particular, prior research yields consistent findings of an association between excess cash holdings and managerial discretionary behavior across countries (Harford, 1999; Dittmar, Mahrt-Smith, and Servaes, 2003; Kalcheva and Lins, 2007; Faulkender and Wang, 2006; Masulis, Wang, and Xie, 2007; Harford, Mansi, and Maxwell, 2008). Kalcheva and Lins (2007) examine national-level institutional characteristics and find that the extent of investor protection is negatively related to cash holdings. Furthermore, Dittmar Mahrt-Smith, and Servaes (2003) find evidence that firms in countries with weaker investor protection hold more cash, and they argue that this is because entrenched managers are precluded from engaging in cash flow diversion when investor protection is strong. Wynn (2008) includes excess cash as a proxy for liability coverage, arguing that cash has the potential to indemnify the firm in civil and criminal liability cases. Canadian firms cross listed in the US are less likely to voluntarily disclose bad news, and less timely with the bad news, when they hold more excess cash. Winn (2008) finds that excess cash is a stronger indicator of firms not taking early responsibility for bad news than the amount of $\mathrm{D} \& \mathrm{O}$ insurance held by the firm.

Auditors encounter litigation related to their role as delegated monitors of corporate ethics as well as their role of conducting a quality audit successful in the detection and disclosure of material misstatements (DeAngelo, 1981). Accordingly, regulators and professional organizations have sought to reformulate the role of auditors as agents of social change (Chambers, 2014) who will better serve society in the $21^{\text {st }}$ century by having "more of the adaptability of farmers than the regimented approach of police or the heroism of masked crusaders." (Sarens, Lenz, and Decaux, 2016). As change agents, auditors assume liability, while 
positioning themselves within a framework of governance institutions, where the institutions and investors rely on the auditor for information and monitoring capabilities. Auditors serve as intermediaries in two ways, (1) by providing reputational cover for financial reporting and (2) as "gatekeepers" (Coffee, Jr. 2001). As reputational intermediaries, auditors lend the audit firm's name for credibility to the client's financial reporting and disclosures, and the reporting is used by stakeholders who seek to enforce their rights. As gatekeepers, auditors are relied upon to monitor behavior of corporate insiders (Coffee, Jr. 2001). Therefore, when stakeholders external to the firm are empowered through the legal framework to hold management accountable, auditors have oversight for the reporting that is relied upon to support litigation. Alternatively, when more regulation is placed directly on the firm's internal management (e.g. the Foreign Corrupt Practices Act rules regarding bribery), auditors may be called upon to serve as gatekeepers to monitor management's behavior.

The literature indicates that agency conflict between managers and shareholders may heighten auditor perception of liability (Gul et al. 1998; Gul and Tsai, 2001; Carcello et al., 2002; Larker and Richardson, 2004; Hay, Knechel and Ling, 2008; Griffen, Lont, and Sun, 2009). Research also indicates that excess cash holdings (1) are reflective of agency problems within the firm and (2) lend themselves to misuse by managers seeking to entrench themselves in power. As a result of the agency costs associated with excess cash holdings, auditors assign U.S. firms with larger cash hordes (i.e., high excess cash) higher audit fees (Gleason, Greiner, and Kannan, 2017).

TIn that the capital markets are increasingly globalized, auditors contend with greater complexity from their clients, and audit fees are significantly higher for foreign firms traded in the US as a result (Bronson, Ghosh and Hogan, 2018). Across countries, there are differing 
capital market protections that rely on auditors as information intermediaries and create incentives for high quality audits through required disclosures, the threat of litigation, and corresponding penalties (DeFond and Zhang, 2014). We use a sample of firms incorporated outside of the U.S. but traded publicly on the main U.S. stock exchanges, the NASDAQ-AMEX and the NYSE (i.e., "foreign incorporated firms") to investigate accountant liability and other institutional characteristics impact auditor pricing of excess cash holdings. We find that auditors of foreign incorporated firms perceive higher risk for firms holding greater levels of excess cash, and that pricing is conditioned on country level governance.

Taken together, we provide evidence that audit fees reflect the risk associated with potential agency costs arising from excess cash holdings, exacerbated by accountant liability statues and the institutional governance factors, for foreign incorporated firms traded in the US. Findings of this paper are relevant to investors, auditors and standard setters because we quantify the relative effects of policy across countries.

\section{Theoretical Framework and Hypothesis Development}

\subsection{Agency Costs of Excess Corporate Cash Holdings}

Optimal cash holdings are achieved through a tradeoff between the benefits to a firm of holding liquidity and the corresponding costs. Firms hold highly liquid assets to insure against shortages resulting from uncertainty and the potential costs from selling non-cash assets to alleviate the unexpected shortage (transactions motive), to support daily operations, and to avoid external financing costs to take advantage of positive NPV projects (Keynes, 1936; Myers and Majluf, 1984; Opler, Pinkowitz, Stulz, and Williamson, 1999; Graham and Leary, 2019). Han and Qiu (2007) argue that intangible-intensive firms facing capital market constraints tend to hold greater amounts of cash, which is consistent with the precautionary motive for cash holdings. Damodaran (2005) conclude that firms in emerging countries and firms in countries 
with weaker financial sector development should hold more cash. Chen and Chuang (2009) find that high tech firms, characterized by high burn rates, high financing costs, and high information asymmetry between insiders and shareholders, exhibit a higher optimal level of cash holding. These results indicates that, under certain conditions (such as a rich investment environment), optimal cash holdings are higher for some firms, and higher cash holdings per se may not yield from poor performance, particularly in the presence of good governance (Mikkelson and Parch, 2003).

Levels of excess cash beyond the optimal amount pose a particular agency conflict risk, because highly liquid assets are tunnelable, or easily divertible to activities that afford personal rents to managers and destroy shareholders' value (Myers and Rajan, 1995; Pinkowitz, Stulz and Williamson, 2006). Accordingly, research indicates that the marginal dollar value of liquidity declines subject to the governance quality of the firm (Faulkender and Wang, 2006) and Harford, Wang, and Zhang (2017) find that a one standard deviation increase in the cash ratio of foreign firms is associated with a reduction in marginal value of cash by $\$ 0.31$, indicating that investors discount the value of foreign firms' cash holdings. ${ }^{1}$

Explanations of the declining marginal value of cash holdings can be classified into three broad concepts. First, highly liquid assets typically earn yields lower than the cost of capital (Azar, Kagy, and Schmalz, 2016; Graham and Leary, 2018). ${ }^{2}$ Secondly, the expected tax effect of returning excess cash holdings to shareholders reduces the asset's value (Riddick and Whited, 2009). Third, when firms hold cash in excess of optimal amounts, managers are more likely to

\footnotetext{
${ }^{1}$ We differentiate our study from those that examine free cash flows. Free cash flows are cash flows available for distribution to investors after contractual claimants such as creditors and taxation authorities have been paid and necessary capital investments have been made. Excess cash, examined here, refers to cash holdings above the predicted optimal cash holdings needed for daily transactions, to take advantage of unforeseen opportunities, or as a precaution against an unexpected adverse event such as a liquidity crisis.

${ }^{2}$ At the extreme, firms forgo any returns if they hold portions of their cash in non-interest bearing checking accounts (Azar et al. 2016 and footnote 19 in Graham and Leary, 2018)
} 
sub-optimally invest the balances, especially when managerial incentives do not align with those of shareholders. ${ }^{3}$ Gao, Harford and $\mathrm{Li}$ (2013) find that private firms, which are subject to fewer agency costs, hold half as much cash public firms, which suffer from the separation of ownership and control.

Further, the agency costs associated with excess cash holdings have been attributed to weak governance and institutional voids. Excess cash holdings have been extensively tied to managerial discretionary behavior across countries (Harford, 1999; Dittmar, Mahrt-Smith, and Servaes, 2003; Kalcheva and Lins, 2007; Faulkender and Wang, 2006; Masulis, Wang, and Xie, 2007; Harford, Mansi, and Maxwell, 2008). Liquid assets are not as highly valued in countries with weak investor protection, because the incentives to tunnel are high and the risk of prosecution is low (Pinkowitz, Stultz, and Williamson, 2006). Kalcheva and Lins (2007) examine national-level institutional characteristics and find that the extent of investor protection is negatively related to cash holdings. Furthermore, Dittmar Mahrt-Smith, and Servaes (2003) find greater cash holdings in presence of weaker investor protection. This is because entrenched managers are precluded from engaging in cash flow diversion when investor protection is strong.

In addition, managers may use excessive cash holdings to evade the market for corporate control as a disciplinary mechanism, by fending off a takeover that would remove them from power, or to engage in control-enhancing acquisitions (Harford, 1999; Masulis, Wang, and Xie, 2007). Harford (1999) and Harford, Mansi and Maxwell (2008) find that more entrenched managers (firms with more anti-takeover provisions) hold more cash and make value destroying acquisitions.

\footnotetext{
${ }^{3}$ Other explanations include 1) highly liquid assets typically earn yields lower than the cost of capital (Azar, Kagy, and Schmalz, 2016; Graham and Leary, 2018); 2) the expected tax effect of returning excess cash holdings to shareholders reduces the asset's value (Riddick and Whited, 2009).
} 
Finally, Song and Sun (2017) find that investors' misevaluation of equity within firms leads to greater holdings of excess cash, which thereby yields a greater incidence of corporate misconduct, and document a significant, positive relationship between excess cash holdings, managers hiding bad news, and corporate misconduct. In particular, they estimate that firms sued for corporate misbehavior have $4.2 \%$ more excess cash than non-misconduct firms. Taken together, the literature suggests that greater excess cash holdings worldwide are associated with a lower quality institutional framework and greater agency conflict.

\subsection{Pricing of Excess Cash Holdings of Foreign Incorporated Firms}

Auditors are part of the corporate governance framework and play a central role in the provision of information to capital market participants (Watts, 1977; Watts and Zimmerman, 1981; Benston, 1980). In countries with relatively weak legal environments, top tier auditors are hired to take on a bonding role when firms reach out for debt or equity financing (Choi and Wong 2007). As "delegated contractors," acting on behalf of shareholders, they are charged with the responsibility to "both discover and report a breach on a given client's audit" (DeAngelo, 1981), and in doing so, auditors lend reputational credibility to the financial statements of the firm (Coffee Jr., 2001). Furthermore, Coffee Jr. (2001) refers to the auditor in an oversight role as that of a a "gatekeeper". The information provided to stakeholders (shareholders, creditors, employees, suppliers, and regulators) through the audit is meaningful, although the shareholder bears the audit cost. As noted by DeAngelo (1981), "in at least some cases, the provision of audited financial statements is the least-cost contractual response to owner-manager and intra-owner conflicts of interest" (DeAngelo, 1981). 
The audit fee model (Simunic, 1980) indicates that audit fees are comprised of two components: the cost of performing the audit, and the likelihood that the auditor will have to pay for losses attributed to the audit client. The risks for audit firms may arise from audit failures and risks from their association with an audit client, both of which can result in litigation brought against the auditor (see Zimbelman, 1997; Glover, Prawitt, Schultz, and Zimbelman, 2003; Bedard and Johnstone, 2004; Menon and Williams, 1994; Houston, Peters, and Pratt, 1999; Johnstone, 2000; Lyon and Maher, 2005; Houston, Peters, and Pratt 2005, Stanley, 2011). Even a weak liability claim may take over three years to litigate, costing an average of $\$ 3.7$ million per claim (Palmrose, 1997) ${ }^{4}$.

From an auditors' perspective, excess cash holdings may be regarded as either an audit risk factor or a business risk factor. As an audit risk factor, large holdings of highly liquid assets can be diverted towards value destructive purposes, and once they are no longer available for investment, managers may rely on the manipulation of accounting performance to hide the misappropriation. Excess cash holdings may represent a business risk factor if managers engage in value destructive behavior that could trigger shareholder litigation where the auditor is named as a defendant.

Accordingly, evidence suggests that auditors assign greater risk to clients who have greater cash holdings and price these clients accordingly, to compensate for direct and indirect losses due to potential litigation. Free cash flow has been investigated by Griffen, Lont, and Sun (2009), who find that firms with higher growth opportunities are assessed higher audit fees if they exhibit high free cash flows, as firms should retain free cash flows for future growth,

\footnotetext{
${ }^{4}$ Litigation risk has been tied to higher audit fees in a number of contexts, including initial public offerings (Venkataraman, Weber, and Willenborg, 2008) and varying levels of institutional ownership (Cassell, Drake, and Dyer, 2018).
} 
although their study does not assess excess cash holdings. Examining a sample of U.S. publicly traded firms, Gleason, Greiner, and Kannan (2017) find that auditors more aggressively price American clients with excessive cash in when external monitoring is low because firm governance is weak.

Country-level institutional factors affect the liability component of the audit. Because of institutional risk, audit fees vary relative to country-level factors such as investor protection, disclosure, enforcement, and legal regime (Choi, Kim, Liu, and Simunic, 2009). Empirical studies have identified that auditors charge higher fees to audit clients that are likely to bribe foreign officials (Lyon and Maher, 2005). Furthermore, firms that are cross-listed in countries with a different legal regime than the home country also exhibit higher fees (Choi, Kim, Liu, and Simunic, 2009). Seetheraman, Gul, and Lynn (2002) examine UK firms cross listed in the United States and evaluate the liability differential between the US and UK. The difference between the US and UK litigation regimes results in an audit fee premium assessed by UK auditors. Bronson, Ghosh and Hogan (2018) examine American Depository Receipts (ADRs) and find that audit fees for ADR firms are significantly higher than for non-cross listed firms, attributable to greater work required as well as to greater litigation risk.

Based on the literature regarding the agency costs of excess cash holdings worldwide we present our first hypothesis in the alternative form as follows:

H1: Audit fees for foreign incorporated firms traded publicly in the US are positively related to excess cash holdings.

Auditor pricing of excess cash holdings may vary across countries of incorporation for foreign incorporated firms listed in the U.S. because they lead to heightened litigation risk to the auditor, to greater billable hours, or both. We examine auditor pricing of excess cash across levels of accounting disclosures, legal enforcement, liability, and shareholder rights. 


\subsection{Auditor Pricing of Excess Cash Holdings Across Levels of Accounting Disclosure}

Although prior research indicates that excess cash holding is discounted by capital markets, this discount is significantly less pronounced in the presence of greater disclosures, as they reduce managers' ability to engage in wealth expropriation by giving investors greater insight into the activities of management, enhancing their monitoring role (Huang and Zhang, 2012). As Bell, Filatotchev and Rasheed (2012) state: "in international financial markets there is a greater potential for an unequal distribution of information between national and foreign investors. An important source of such asymmetry is uncertainties regarding the codified rules regulating the behavior and activities of company insiders in foreign markets."

Pagano, Randl, Röell, and Zechner (2001) and Ahearne, Griever and Warnock (2004) stress the importance of informational barriers resulting from different national accounting standards and practices. In countries with low accounting disclosure regulations, the auditor must spend time organizing and requesting information that needs to be disclosed under U.S. accounting laws, but not under the laws of the country of incorporation. Furthermore, auditors may not have access management estimates or judgments that could expose them to liability.

According to empirical findings, Taylor and Simon (1999) show that the disclosure environment is positively related to audit fees, because the disclosures increase the amount of audit work required and auditors' assumed liability for audit failures. Their investigation was conducted across twenty countries worldwide. Chung and Narasimhan (2002) find that the additional disclosure required in developed countries is one of the reasons audit fees are higher than for developing countries than for developed countries. In countries where more disclosures are required, firms are more likely to choose a large, reputable audit firm (Fargher et al. 2001), and the level of disclosures required in the country increases audit fees (Choi, Kim, Liu and 
Simunic, 2009; Fargher et al. 2001; Wingate 1995). Auditors also serve as intermediaries, lending credibility to the increased disclosures (Fargher et al. 2001).

While firms from low disclosure countries will require more work to obtain the items required for disclosure in higher disclosure countries where they are traded, such as the US, several countries such as Australia, Switzerland, Finland and Great Britain (CIFAR disclosure scores $80,80,83$, and 85 respectively) require more accounting disclosures than the US (CIFAR score of 74). All firms in our study must meet the minimum disclosure requirements in the US, and firms from higher disclosure countries require more disclosure auditing than firms from low disclosure countries. If auditors perceive client agency problems due to excess cash as complicating the audit of disclosures, or reducing the reliability of managerial estimates, they may assess a risk premium to audit fees.

Taken together, the literature regarding the agency implications of excess cash holdings and the additional work and risk associated with greater levels of disclosure suggest that auditor pricing of excess cash holdings will be higher in greater disclosure environments than in lower disclosure environments.

H2: Audit fees for foreign incorporated firms traded publicly in the US are positively related to excess cash when the home country requires more accounting disclosure.

\subsection{Auditor Pricing of Excess Cash Holdings Across Strength of Legal Enforcement}

Enforcement of the rule of law refers to the judicial system's efficiency and integrity, the level of corruption involving special payments or bribes to officials, and the level of the traditional rule of law in the country of incorporation (La Porta, Lopez-de-Silanes, Shleifer and Vishny, 1998 (LLSV)). From a global perspective, the enforcement of legal rights across countries impacts the misallocation of excessive cash holdings (Dittmar, Mahrt-Smith, and Servaes, 2003; Kalcheva 
and Lins, 2007). In turn, this affects auditor perception of the quality of internal controls and financial reporting documents. LLSV (1998) argue that financial decision-making and the quality of valuation depend on the strength of shareholder rights enforcement. The auditor, however, answers to the firm's American shareholders and the U.S. legal system in addition to the country of incorporation legal system. They must expend effort to detect material misstatements or accounting fraud, or contend with litigation.

Two articles, Taylor and Simon (1999) and Fargher et al. (2001), examine a sample firms from different countries using a regulation score from Cooke and Wallace (1990). They identify an audit premium for firms in countries with stronger regulation of required disclosures. Bronson et al. (2018) test a combined enforcement proxy comprised of judicial efficiency, rule of law, and corruption as a determinant of audit fees, but the effect of enforcement was not significant. Choi, Kim, Liu and Simunic (2009) find that a greater enforcement differential between the home and foreign country results in a proportionally higher audit fee. The application of this finding implies that firms traded on US exchanges where legal enforcement is assigned a high score have higher audit fees when their home country enforcement is lower. Therefore, firms pay auditors a higher premium when enforcement in the home country is weaker relative to the country where the stock is cross-listed. A relatively stronger legal regime supports management integrity, reducing engagement risk for auditors because management is held to a high standard. However, when agency problems exist within the firm, the accountability for misallocation of resources remains with the auditor.

Legal regimes can use direct enforcement on wrongdoers, but this may lack effectiveness if too many of the wrongdoers are undeterred by the consequences, the behavior is too difficult to detect, or the related administrative costs are too high (Alzola 2017). Relying on a third party 
gatekeeper to identify violations of the rules and the people or entities involved is an efficient strategy (Coffee, 2002). Auditors have access to inside information, and the cost of their oversight and enforcement is passed on to investors by way of the audit fees (Alzola, 2017; Rusch Factors, Inc. v. Levin, 284 F. Supp. 85: 91). The product of auditing is predicated on the accounting firm's investment in licenses and reputation. Auditors are more sensitive to consequences because they have more to lose if wrongdoing is attributed to their firm, and in most cases the auditors have less to gain from the misconduct. Auditors are efficient and effective gatekeepers for the legal regime, but acting as a gatekeeper is expensive for auditors in terms of billable hours and prospective risk (which may not be a fair expectation of auditors (Boatright 2007)). Heightened agency concerns within the firm may increase the auditor's risk associated with their role as gatekeeper, resulting in an audit fee premium.

Based on the literature regarding legal enforcement, our third hypothesis is as follows:

H3: Audit fees for foreign incorporated firms traded publicly in the US are positively related to excess cash holdings when the home country has stronger legal enforcement.

\subsection{Auditor Pricing of Excess Cash Holdings Across Accountant Liability Regimes}

Accountant liability refers to national, institutional constructs in securities law that enact penalties to auditors from levels of "failure". Depending on the country, accountants may be held liable publicly or via laws that facilitate private, civil litigation. Costs for accountants and auditors are incurred in the form of performance obligations, financial judgements, or criminal prosecution (La Porta, Lopez-de-Silanes and Shleifer, 2006). La Porta et al. (2006) provide an example of Argentine securities law, which specifies that a failure to properly disclose required information in the IPO prospectus potentially yields a formal warning and fines to both the issuer 
and the accountants, "regardless of whether the omission was intentional or a result of negligence" (Section 10, Law 17, 881).

La Porta et al. (2006) defines sanctions that can be imposed on auditors under national securities law and exchange requirements: 1. liability standard for accountants; 2 orders accountant; 3. criminal accountant and 4. criminal. Liability standard for accountants refers to the nature of the burden of proof required for an accountant to be penalized for failure to disclose in an offering statement. A score of zero means that a penalty will only be applied if intent to mislead can be demonstrated or if no restitution is available. For Argentina, the score of 0.33 reflects the standard of proof of negligence for penalties to apply. On the other hand, for Canada, the liability standard score is 1 , because investors require a lower burden of proof for penalties to apply to accountants; investors must only demonstrate that the audited financial statements contain a misstatement. A score of zero means that a penalty will only be applied if intent to mislead can be demonstrated or if no restitution is available. Germany, with a score of zero, has the most attractive terms for auditors in the European Union, capping and limiting liability (Piot 2005; La Porta et al. 2006).

The orders accountant variable is a measure of disruption of auditor autonomy and refers to stop and do orders requiring the accountant to stop and desist from various activities, or to do various activities, in the event that a prospectus is defective. In other words, accounting work autonomy can be restricted as a consequence of liability, or they can be ordered to perform additional work as a cure or penalty (La Porta et al. 2006). For Argentina, the orders accountant score is 0 , because the accountant is not mandated to stop activities or perform them should a prospectus be found to be defective. For Canada, the stop and do variable is 1 , because the 
accountant can be required to engage in a variety of activities and can be required to desist from a variety of activities if a defect is found.

The third variable refers to the standard applying to criminal penalties which can be levied on an accountant if material information is omitted from a prospectus. This variable is defined as zero, as in the case of Argentina, when the accountant cannot be held criminally liable when the prospectus is misleading and 1 for Canada because the accountant can be held criminally liable even if they are negligently unaware that the financial statements were misleading. The score for Egypt is 0.5 , because the auditor can be held criminally liable if they were aware that the disclosures were misleading. Other countries, such as Denmark, with a score of zero, assign no criminal penalties, or require knowledge of the error (La Porta et al. 2006). The fourth variable includes the third variable, criminal accountant, and expands the scope to include liability for the firm's directors and underwriter. Key officers for the accountant, directors and underwriter are also subject to this liability.

Each of these variables presents a different view of the liability of the auditor. The higher the liability standard, the greater the exposure to the auditor because a lower burden of proof is required in order to apply penalties to the auditor. The higher the stop and do order variable, the greater the liability to the auditor because the auditor has less autonomy over corrective actions and may be required to invest additional billable hours in the event of misstatements as a corrective action. The higher the criminal accountant variable, the higher the auditor liability, because the burden of proof is lower to enact criminal penalties.

Managers can be encouraged to act with greater integrity when they need certification from auditors, and greater auditor liability implies greater consequences for auditors to overlook misstatements (Bhattacharya 2006). Enforcement that relies on auditor liability for their clients is 
so effective that some evidence suggests it is more effective than public enforcement (La Porta et al., 2006; Bhattacharya 2006). For example, Wysocki (2004) finds that when third parties can more easily access the deep pockets of the firm's auditor, the firm is less likely to manage earnings. As intermediaries of governance, auditors incur the additional cost of liability related to the client and the cost of gathering additional audit evidence for higher risk clients (Choi et al. 2008). To the extent that this liability is an incentive for the client's accountants, directors and underwriter to act with integrity, it benefits auditors. However, if there is misconduct, the auditor is subject to liability as the gatekeeper. Recent evidence suggests that the adoption of universal demand (UD) laws in United States jurisdictions, which limit the ability of shareholders to sue managers and auditors, resulted in a reduction of audit fees in states that adopted these laws and an improvement in financial reporting quality. The reduced audit fees are attributed to lower effort as well as lower litigation risk for auditors (Bilokha, Kong, and Micale, 2019).

Dye (1993) refers to a liability component of the audit fee as the option value of litigation. To determine the amount of evidence required in an audit, auditors start with an assessment of audit risk. Management integrity and factors that could compromise integrity are an important part of this assessment, which also determines billable hours and the option value of litigation. Therefore, the variation across regimes in auditor liability affects audit fees (Choi et al. 2008), and the risk of a greater likelihood of faults in management integrity, encouraged through excess cash holdings, may increase auditor assessment of the option value of litigation. If auditors perceive that excess cash holdings increase the option value of liability, the audit fee should reflect this transfer of agency cost, relative to the liability laws in the firm's home country. This leads to our third hypothesis. 
H4: Audit fees for foreign incorporated firms traded publicly in the US are positively related to excess cash holdings when the country of foreign incorporation ascribes more liability to accountants.

\subsection{Auditor Pricing of Excess Cash Holdings Across Shareholder Rights Regimes}

Agency costs are negatively related to shareholders' ability to act as agents of corporate governance, who monitor and discipline managers (Gompers, Ishii and Metrick, 2001). Strong shareholder rights in the U.S. empower shareholders to force managers to disgorge excessive cash holdings through the proxy contest process (Faleye, 2004). Globally, the strength of shareholder rights critically ensures quality corporate governance (LLSV, 1998). Dittmar, MahrtSmith, and Servaes (2003) and Lins and Kalcheva (2007) find that managers in weaker shareholder rights countries tend to hold greater cash balances. These cash balances are discounted by the markets. After controlling for the costs of accessing the external capital markets, they attribute this to shareholders' inability in weak shareholder rights environments to force managers to reduce excessive cash balances through share repurchases or special dividends. Given that greater shareholder rights indicate better governance quality and firm monitoring, auditors likely perceive that greater monitoring of top-level executives reduces litigation risk; shareholders will less likely sue the client.

Zhang and $\mathrm{Yu}$ (2016) find that greater shareholder power may yield greater oversight of auditors, resulting in higher audit fees, and Beck et al. (2013) find that higher director and officer $(\mathrm{D} \& \mathrm{O})$ insurance premiums, which are associated with greater litigation risk, are positively associated with audit fees. Given the literature regarding shareholder rights and quality of governance, we anticipate finding that regimes providing greater shareholder empowerment place higher demands on auditors to monitor management and to ensure high quality reporting for shareholder intervention. Therefore, our fourth hypothesis follows. 
H5: Audit fees for foreign incorporated firms traded publicly in the US are positively related to excess cash holdings when the corporate legal code of the home country provides for stronger shareholder rights.

\section{Data and Empirical Approach}

\subsection{Data}

We obtain our sample of foreign incorporated firms traded on the NASDAQ-AMEX and NYSE in the United States from Standard and Poor's Research Insight database for the years 2003 to 2016. We retrieved financial statement data for all foreign incorporated firms listed in the United States, which includes American Depository Receipts (ADRs) and direct listings, excluding financial and utility firms (SIC 4400-4999 and SIC 6000-6999). We obtained all data on audit fees, auditor size, financial statements, restatements, and auditor tenure from Standard and Poor's Audit Analytics database, GDP data by country, and stock price data from the University of Chicago's Center for Research in Securities Prices (CRSP). Our sample consists of 863 foreign incorporated firms publicly traded in the US. The sample consists of 300 ADRs, 571 direct listings, and eight firms that changed from direct listing to ADR over the time period of the study. The final sample includes 5,808 firm-years. Legal and institutional environment data derived from the website of Rafael La Porta, http://faculty.tuck.dartmouth.edu/rafaellaporta/research-publications, from the dataset accompanying LLSV (1998).

\subsection{Audit Fee Model}

In order to assess auditor pricing of excess cash holding for a sample of foreign incorporated firms listed in the U.S. We follow the audit fee model of Bronson, Ghosh and Hogan (2018) and regress audit fees on our proxy for excess cash holding (XSCASH), and audit fee determinants identified in Bronson et. al. (2018). The model is as follows: 


$$
\begin{aligned}
& L N F E E_{i t}=\mathrm{a}_{0}+\mathrm{a}_{1} X S C A S H_{i t}+\mathrm{a}_{2} L N T A_{i t}+\mathrm{a}_{3} I N V R E C_{i t}+\mathrm{a}_{4} F O R E I G N_{i t}+\mathrm{a}_{5} M A_{i t}+\mathrm{a}_{6} Q R A T I O_{i t}+ \\
& \mathrm{a}_{7} R O A_{i t}+\mathrm{a}_{8} L O S S_{i t}+\mathrm{a}_{9} L E V_{i t}+\mathrm{a}_{10} G R O W T H_{i t}+\mathrm{a}_{11} M K T B_{i t}+\mathrm{a}_{12} R E S T A T E_{i t}+ \\
& \mathrm{a}_{13} X D O P S_{i t}+\mathrm{a}_{14} B U S Y_{i t}+\mathrm{a}_{15} I N I T I A L_{i t}+\mathrm{a}_{16} G C_{i t}+\mathrm{a}_{17} I C F R_{i t}+\mathrm{a}_{18} I C W E A K_{i t}+ \\
& \mathrm{a}_{19} B_{I G N} N_{i t}+\mathrm{a}_{20} U S A U D I T O R_{i t}+\mathrm{a}_{21} L G D P_{i t}+\sum y e a r+\sum \text { industry }+\varepsilon_{\mathrm{it}}
\end{aligned}
$$

See appendix 1 for variable definitions. We control for country level yearly purchasing power parity using the natural log of the adjusted per capita GDP (GDPPC) following Choi, Kim, Liu and Simunic, (2008 and 2009), as well as year and industry fixed effects in all analysis.

We further assess the incremental audit pricing of excess cash holdings in the presence of increased disclosure, stronger legal enforcement (H2), higher auditor liability environments (H3), and greater shareholder rights (H4) using a two stage, least squares model following the methodology from Leuz et al. (2003). The country level variables are identified as endogenous. The country's legal origin, (CIV_COM), GDP per capita (LGDP) and the relationship of the home country to the firm (ADRFirm) are used as instruments.

$$
\begin{aligned}
& L N F E E_{i t}=\mathrm{a}_{0}+\mathrm{a}_{1} X S C A S H_{i t}+\mathrm{a}_{2} \text { Disclosure }+\mathrm{a}_{3}(X S C A S H * \text { Disclosure })_{i t}+ \\
& \sum F e e \_ \text {Determinants }+\sum y e a r+\sum \text { industry }+\varepsilon_{\mathrm{it}} \\
& \text { LNFEE }_{i t}=\mathrm{a}_{0}+\mathrm{a}_{1} X S C A S H_{i t}+\mathrm{a}_{2} \text { Enforcement }+\mathrm{a}_{3}\left(X S C A S H * \text { Enforcement }_{i t}+\right. \\
& \sum \text { Fee_Determinants }+\sum y e a r+\sum \text { industry }+\varepsilon_{\mathrm{it}} \\
& \text { LNFEE }_{i t}=\mathrm{a}_{0}+\mathrm{a}_{1} X S C A S H_{i t}+\mathrm{a}_{2} \text { Auditor_Liability }+\mathrm{a}_{3}(X S C A S H * \text { Auditor_Liability })_{i t}+ \\
& \sum \text { Fee_Determinants }+\sum y e a r+\sum \text { industry }+\varepsilon_{\mathrm{it}} \\
& L N F E E_{i t}=\mathrm{a}_{0}+\mathrm{a}_{1} \mathrm{XSCASH} i t+\mathrm{a}_{2} \text { Sharholder_Rights }{ }_{i t}+\mathrm{a}_{3}(X S C A S H * \text { Shareholder_Rights })_{i t}+ \\
& \text { EFee_Determinants }+\sum y e a r+\sum \text { industry }+\varepsilon_{\mathrm{it}}
\end{aligned}
$$


The Disclosure proxy is the Center for International Financial Accounting Research disclosure measure $(C I F A R)^{5}$. To measure Enforcement, two variables are employed, 1) the efficiency of the judiciary $\left(E F F \_J U D\right)$; and 2)the rule of law measure (RuleLaw_2000). The Auditor_Liability proxies from La Porta et al (2006) are: 1) BURDEN, which measures whether the plaintiff must prove negligence; 2) $O R D \_A C C$ which is a measure of to stop or to do orders that can be imposed on auditors if there are defects in the prospectus, 3) CRIM_ACC reflects an index of criminal sanctions that may be applied to to accountants and 4) CRIMINAL which combines the sanctions for accountants $\left(C R I M \_A C C\right)$ along with sanctions for criminal liability of the firm's directors and underwriter. A higher score reflects a lower burden of proof, which creates greater risk for auditors; 5) Liab_Score, a principal component score combining the first four variables. The Shareholder_Rights proxies are: 1) ANTIDIR, a measure of shareholder rights over the board of directors; 2)1Share_1Vote, an indication that one share equals one voting right; ; 3) XCONST, an index of the institutional constraints on the decision-making power of chief executives; and 4) Mgr_Score, a principal component score combining the first three variables. See Appendix 1 for variable definitions.

\section{[Appendix 1 About Here]}

The dependent variable, $L N F E E_{i t}$, is the natural $\log$ of the total audit fees as reported in the Audit Analytics Opinions File. XSCASH, our measure of excess cash holdings, is calculated as per Dittmar and Mahrt-Smith (2007) and represents the residual from the following fixed effects panel regression.

$$
\begin{aligned}
\operatorname{Ln}(C A S H / N A)_{i t} & =\beta_{0}+\beta_{1}(\operatorname{LnNA})_{i t}+\beta_{2}(F C F / N A)_{i t}+\beta_{3}(N W C / N A)_{i t}+\beta_{4}(\text { IndustrySigma })_{i t} \\
& +\beta_{5}(\text { MV/NA })_{i t}+\beta_{6}(\text { RD/NA })_{i t}+\sum \text { Year }+\sum \text { Industry }+e_{i t}
\end{aligned}
$$

\footnotetext{
${ }^{5}$ This proxy was used in Kwok and Tadesse (2006), Baik, Kang, Kim and Lee (2013), Jandik and Kali (2009), and Cumming and Walz (2010). A higher DISCLOSURE index indicates more required accounting disclosures.
} 
where subscripts represent firm $i$ at period $t$. All Equation (5) variables are scaled by net assets, calculated as total assets less cash and cash equivalents. $\operatorname{Ln}(C A S H / N A)$ is the natural $\log$ of cash and cash equivalents divided by net assets; LnNA is the natural log of net assets; FCF is free cash flow, determined by subtracting interest and taxes from operating income; $N W C$ is net working capital (current assets- current liabilities - cash and cash equivalents); IndustrySigma is the average standard deviation of industry cash flows over the previous 10 years; $M V$ is the market value of the firm ${ }^{6}$; and $R D$ is $\mathrm{R} \& \mathrm{D}$ expenditures.

Table 1 provides the distribution of the sample (firm years) by year, country of incorporation, and industry.

\section{[Table 1 About Here]}

The distribution of firm-years over the 2003-2017 time period is presented in Table 1, Panel B. The sample remained stable over time, with the greatest number of observations in 2003 (8.12\% of the total firm-years) and the least in 2010 (5.94\% of the total). The sample distribution across industries is provided in Table 2, Panel B. The majority of firm years are in SIC codes 2000 - 3999, manufacturing (54.08\%) and 7000-7999, services $(15.74 \%)$.

The distribution across countries of incorporation is presented in Table 1, Panel C. Our sample spans 29 countries, with the greatest number of firm years arising from Canada (40.92\%), Israel $(15.72 \%)$, and the UK $(6.89 \%)$.

Table 2 provides the descriptive statistics of variables used in tests of our hypotheses.

\footnotetext{
${ }^{6}$ We use an instrumental variable approach to control for potential endogenous relationship between audit fees and excess cash holdings. Specifically, greater growth may entice managers to hold excess cash to take advantage of these opportunities. Also, auditors may charge higher fees in the presence of greater growth as a compensation for additional audit effort. In doing so, we determine a fitted MV/NA, using 3-year lagged sales growth (Sales Growth) as an instrument according to the following equation $M V_{i, t} / N A_{i, t}=a_{0}+a_{1} \operatorname{Ln}\left(N A_{i, t}\right)+a_{2}\left(F C F_{i, t} / N A_{i, t}\right)+a_{3}\left(N W C_{i, t} / N A_{i, t}\right)+a_{4}\left(R D_{i, t} / N A_{i, t}\right)+a_{5}$ Sales Growth $+\varepsilon_{i, t}$ All variables are defined above.
} 
[Table 2 About Here]

The sample mean (median) natural log of audit fees $(L N A F)$, the dependent variable is 13.75 (13.71), which is equivalent to mean (median) value of $\$ 3.74$ (\$0.90) million. Excess cash has a mean (median) value of $0.87(0.73)$, while the lower and upper quartiles are 0.00 and 1.46 , respectively. The minimum value of 0.00 is due to our specification of transposing all negative values to 0 , as our focus is on the positive excess cash holdings.

The impact of home country institutional framework proxies on auditor pricing of excess cash holdings is examined in Hypothesis 2. The first is DISCLOSE, the percentage of ninety possible accounting disclosures required in a country, and the second is the efficiency of the home country's judicial system (EFF_JUD). The sample mean (median) DISCLOSE is $76.2 \%(83.3 \%)$, and mean (median) $E F F \_J U D$ is 9.14 (9.25), with a minimum of 4.75 and a maximum 10.00 .

We rely on multiple home country auditor liability risk proxies (BURDEN_ACC, CRIM_ACC, $O R D \_A C C, B D N \_P R O O F$, and the common factor score $\left.A U_{-} L I A B\right)$. Mean scores for $B U R D E N \_A C C, C R I M \_A C C, O R D \_A C C$, and $B D N \_P R O O F$ are $0.76,0.70,0.72$, and 0.73 , respectively. These scores result in a mean (median) liability factor score $\left(A U_{-} L I A B\right)$ of 0.00 (0.27), respectively. As for the shareholder rights treatment proxies, we use $C U M U_{-} V O T$, XCONST, ANTIDIR, and a common score (SHARE_RIGHT). The Mean (median) cumulative voting score (CUMU_VOT) is $0.49(0.00), X C O N S T$ is $6.65(7.00)$, ANTIDIR, an index from one to six representing the number of rights shareholders retain over the board of directors, is 3.99 (5.00). The mean (median) common factor (SHARE_RIGHT) is $0.00(0.01)$. 
Table 2 also presents descriptive statistics for audit fee determinants identified in prior literature. For our sample of foreign incorporated firms, the mean natural log of total assets (LNTA) is 6.885, equivalent to approximately $\$ 12.54$ million. Our sample has a mean leverage of $24.8 \%$ and mean market to book ratio $(M T B)$ of 3.59 . Approximately $75 \%$ of firms in the sample have a December year-end (BUSY) and $86 \%$ engage a Big $\mathrm{N}$ auditor $(B I G N)$. Less than five percent of our sample firm-years have a restatement (RESTATE), 16\% disclosed discontinued operations (XDOPS), and approximately $5 \%$ received a modified going concern opinion $(G C)$, or a weak internal control opinion (ICWEAK). Further, $12.6 \%$ of our sample engaged a U.S. auditor, and the mean national per capita GDP (GDPPC) was \$39,382.29.

\section{RESULTS}

We next present the results of our empirical tests. Table 3 provides the results of our baseline multivariate regression model and a test of our first hypothesis which posits that there is a positive association between audit fees and excess cash holdings.

\section{[Table 3 About Here]}

The excess cash model shown in Table 3 yields results from the test of our first hypothesis. Model 1 analysis finds a positive association between excess cash and audit fees (coeff. 0.068, p-value 0.000) In Model 2, the XSCASH variable is modified. Negative values of excess cash are set to zero to form a positive excess cash variable (XSCASHPOS), and regression results show that it is positively associated with audit fees. The results in Models 1 and 2 indicate that auditors demand a fee premium when foreign incorporated clients have greater excess cash holdings, consistent with our first hypothesis and with Gleason et al (2017), who find a similar 
relationship between excess cash holdings and audit fees for U.S. incorporated firms. Further, this result supports the arguments regarding the agency costs associated with excess cash holdings for firms around the world.

\section{Institutional Framework Hypotheses}

Our second hypothesis relates to accounting disclosures. Table 4 provides the results of tests of Hypothesis 2.

\section{[Table 4 Here]}

The first panel in Table 4 provides the tests of Hypothesis 2, which states that audit fees are positively related to the firm's excess cash holdings when the home country requires greater accounting disclosure. Accounting disclosures increase the billable hours for auditors (Taylor and Simon 1999) and the risk of misstatements in additional disclosures increases the risk component of the audit fee. US-listed firms from countries of incorporation requiring more disclosures exhibit higher audit fees (coefficient 0.027 , p-value 0.000 ), the interaction of excess cash and disclosure is positive (coefficient 0.004, p-value 0.000), indicating that auditors perceive higher risk when clients holding more excess cash are required to disclose more information. This result is also consistent with prior research such as Taylor and Simon (1999) who find that audit fees are higher in countries with greater required accounting disclosure because of the higher workload.

Our third hypothesis relates to accounting disclosures. Table 5 provides the results of tests of hypothesis 3.

[Table 5 Here] 
Table 5 shows the results of tests of Hypothesis 3, that audit fees are positively related firm's excess cash when the country of incorporation has stronger legal enforcement. In Model 1, excess cash and judicial efficiency increase audit fees. Furthermore, the interaction of excess cash with the country's efficient judicial system $\left(E F F_{-} J U D\right)$ increases audit fees. The coefficient of the interaction between excess cash and judicial efficiency is positive, 0.050 , and significant at the $99^{\text {th }}$ percentile. In Model 2, a second proxy for legal enforcement is tested, RULELAW_2000. The coefficient on RULELAW_2000XCASH is positive and highly significant, supporting Hypothesis 3. For both measures of legal enforcement, when firms cross-listed on US exchanges have excess cash, auditors assess a fee premium relative to the strength of legal enforcement in the home country of incorporation.

In Table 6, we present the results of tests of our fourth hypothesis regarding the relationship between audit fees, excess cash and accountant liability.

\section{[Table 6 About Here]}

In the first model in Table 6, the proxy, BURDEN, is tested, a measure of whether the plaintiff must prove negligence to hold the accountant liable. When $B U R D E N$ is equal to 1 , the plaintiff does not have to prove negligence, and the burden falls to the accountant to prove they are not guilty of negligence. The coefficient on the interaction term, BURDENXCASH is positive (0.515) and significant at the $99^{\text {th }}$ percentile, which means that audit fees are higher for firms that hold excess cash when investors have a low burden of proof in litigation against the auditor. In the second model, using $O R D \_A C C$ as the auditor liability proxy, we again find a positive relationship between audit fees, excess cash holdings, and greater auditor liability. When the auditor can be required to do more work to fix defects discovered in a prospectus or to refrain from actions related to clients as a result of error, they exhibit greater concern over excess cash 
holdings. In the third model, using CRIM_ACC as the accountant liability proxy, we find similar results; auditors charge higher audit fees to clients with excess cash holdings when the auditor risks exposure to criminal liability. The fourth model shows the test of the proxy, CRIMINAL, which includes an index of criminal sanctions for accountants, directors, and underwriters. The interaction term, CRIMINALXCASH is 0.892 and is highly significant, supporting Hypothesis 4. Finally, when we use a factor comprised of all four auditor liability proxies, the results indicate that auditors assign higher fees to higher excess cash holding firms when the auditor is exposed to greater liability. The interaction term, Liab_Score is positive and significant at the $99^{\text {th }}$ percentile. These results are all consistent with Hypothesis 4, that auditors assign a fee premium for foreign incorporated firms in the US when the firm holds more excess cash and hails from a home country with higher risk of litigation to auditors.

Table 7 provides the results of tests of our fifth hypothesis, which states that audit fees are positively associated with excess cash holdings when the corporate legal code of the country of incorporation provides for stronger shareholder rights (lower managerial power). We use three proxies for national level managerial power statutes: anti-director (ANTIDIR), cumulative voting (ISHARE_lVOTE), and constraints on executive power (XCONST).

\section{[Table 7 About Here]}

The first model in Table 7 reflects the results of ANTIDIR, the shareholder power proxy. We find that at increasing levels of shareholder rights, auditors assign higher audit fees for firms with greater excess cash holdings, as indicated by the sign and significance of the interaction term, ANTIDIRXCASH. Therefore hypothesis 5 is supported. Model 2 shows that when US crosslisted firms are incorporated in countries with one vote per share voting, auditors assess a fee premium 
for the firm's excess cash holdings. The coefficient on 1SHARE_1VOTEXCASH is 9.089 and highly significant. ISHARE_IVOTE is negative and highly significant in the non-interaction term, which indicates that when the firm has no excess cash, the shareholder rights from ISHARE_IVOTE reduce the auditor's assessment of risk. In Model 3, the interaction term, XSONSTXCASH, is positive (coeff. 0.057, p-value 0.000), supporting hypothesis 5 . When firms are incorporated in a country that provides for greater constraints on executives, auditors are placed in the role of gatekeeper over the shareholders' rights, and accordingly auditors assess a fee premium for the excess cash holdings. Our final shareholder rights proxy is a factor score derived from ANTIDIR, ISHARE_IVOTE, and XCONST. The coefficient of the interaction term, SH_ScoreXCASH, is positive and significant, consistent with the results using the individual variables. Overall, our results indicate that auditors price excess cash holdings higher in stronger shareholder rights regimes. This finding is consistent with the idea that auditors act as gatekeepers to support stronger rights for shareholders, and shareholders fund this service via the firm's higher audit fees.

\section{CONCLUSION}

While suboptimal cash levels impair firm performance, excess cash carries a risk of mismanagement due to agency conflicts, and accordingly, prior research shows that auditors assess higher fees commensurate with the heightened risk of misallocation of these funds and greater workload required to document any efforts of management to disguise poor performance by manipulating accounting data. In this paper, we examine how auditors view the agency costs associated with excess cash holdings in light of country of incorporation disclosures, legal enforcement, accountant liability laws, and the strength of shareholder rights. As country level 
governance is strengthened, there is higher demand for the role of auditors as reputational intermediaries, monitors, and gatekeepers.

This paper is the first to document that auditors price excess cash holdings for clients across national borders, legal systems, disclosure and enforcement regimes, and levels of shareholder. Our study of foreign incorporated firms traded in the US finds that auditors recognize the potential for greater agency conflict when firms hold higher levels of excess cash. The features of the legal system of the country of incorporation also impacts auditor pricing of the agency cost potential associated with greater excess cash holdings. When the country of incorporation legal system provides for more accounting disclosures, stronger legal enforcement, greater auditor liability, and stronger shareholder rights, auditors assign greater fees to companies with higher excess cash holdings, reflective of the liability they face.

Our findings have implications for stakeholders, auditors, and regulators. First, shareholders of foreign incorporated firms should be aware that they incur costs from agency conflict twice: from the potential for suboptimal decisions using excess cash and also from higher audit fees that arise from excess cash holdings. In addition, shareholders need to be aware that in many regulatory and enforcement environments, their ability to discipline managers who misuse excess cash is limited. Auditors should explicitly examine whether excess cash is being held in order to respond to exogenous shocks that could occur (such as the COVID-19 crisis) or due to a weak institutional monitoring environment that facilitates the diversion of liquid assets. Finally, regulators should exhibit heightened awareness of the potential for the misappropriation of cash for foreign listed firms. From an academic perspective, more research should be conducted to examine legal reserves of cash balances and the impact these reserves have on audit 
fees, as well as auditor pricing of firms incorporated in tax haven jurisdictions as well as the appropriate role of the auditor in acting as a mechanism of shareholder rights enforcement. 


\section{References}

Ahearne, A. G., Griever, W. L., \& Warnock, F. E. (2004). Information costs and home bias: an analysis of US holdings of foreign equities. Journal of International Economics, 62(2), 313-336.

Alzola, M. (2017). Beware of the watchdog: Rethinking the normative justification of gatekeeper liability. Journal of business ethics, 140(4), 705-721.

Azar, José, Jean-François Kagy, and Martin Schmalz, 2016, Can changes in the cost of carry explain the dynamics of corporate cash holdings? Review of Financial Studies 29, 2194-2240.

Baik, B., Kang, J. K., Kim, J. M., \& Lee, J. (2013). The liability of foreignness in international equity investments: Evidence from the US stock market. Journal of International Business Studies, 44(4), 391-411.

Beck, P.J., Cao, Z. and Narayanamoorthy, G.S. (2013). Litigation risk and audit fees: The impact of qualitative factors. Available at SSRN: http://dx.doi.org/10.2139/ssrn.2292699

Bedard, J. C., and K. M. Johnstone. 2004. Earnings manipulation risk, corporate governance risk, and auditors' planning and pricing decisions. The Accounting Review 79 (2): 277-304.

Bell, R. G., Filatotchev, I., \& Rasheed, A. A. (2012). The liability of foreignness in capital markets: Sources and remedies. Journal of International Business Studies, 43(2), 107-122.

Benston, G. J. (1980). The establishment and enforcement of accounting standards: methods, benefits and costs. Accounting and Business Research,11(41), 51-60.

Bhattacharya, Utpal. (2006). "Enforcement and its impact on cost of equity and liquidity of the market." Available at SSRN 952698

Bilokha, A., Kong, J., and J. Micale, 2019. Litigation Risk and Stakeholders: Evidence from Audit Fees, Working Paper

Boatright, J. R. (2007). Reluctant guardians: The moral responsibility of gatekeepers. Business Ethics Quarterly, 613-632.

Bronson, S., Ghosh, A., \& Hogan, C. (2018). The Impact of Auditing Oversight, Legal Environment, Regulation and Disclosure on Audit Effort: An Examination of ADR Firm Audit Fees.

Carcello, J., D.R. Hermanson, T.L. Neal, R.R. Riley Jr.Board characteristics and audit fees Contemporary Accounting Research, 19 (3) (2002), pp. 365-384

Cassell, C., Michael S. Drake and Travis A. Dyer. (2018) Auditor Litigation Risk and the Number of Institutional Investors. AUDITING: A Journal of Practice \& Theory 37:3, 71-90. 
Cenco Inc. v. Seidman \& Seidman, 686 F.2d 449, 456 (7th Cir. 1982)

https://casetext.com/case/cenco-inc-v-seidman-seidman

Chambers, R., 2014. Internal Auditors as Agents of Change, Internal Auditor, accessed at https://iaonline.theiia.org/internal-auditors-as-agents-of-change

Chen, Y. R. and Chuang, W. T. (2009), Alignment or Entrenchment? Corporate Governance and Cash Holdings in Growing Firms. Journal of Business Research, 62 (11), 1200-1206.

Choi, J. H., Kim, J. B., Liu, X., \& Simunic, D. A. (2008). Audit pricing, legal liability regimes, and big 4 premiums: Theory and Cross-country evidence.Contemporary Accounting Research, 25(1), 55-99.

Choi, J. H., Kim, J. B., Liu, X., \& Simunic, D. A. 2009. Cross-listing audit fee premiums: Theory and evidence. The Accounting Review 84(5): 1429-1463.

Choi, Jong-Hag, and Tak Jun Wong. 2007. Auditors' governance functions and legal environments: an international investigation. Contemporary Accounting Research 24.1: 13-46.

Chung, S., \& Narasimhan, R. (2002). An international study of cross-sectional variations in audit fees. International Journal of Auditing, 6(1), 79-91.

Coffee Jr, J. C. (2001). Understanding Enron: It's about the gatekeepers, stupid. Bus. Law., 57, 1403.

Coffee Jr, J. C. (2002). Racing towards the top?: The impact of cross-listings and stock market competition on international corporate governance. Columbia law review, 1757-1831.

Cooke, T. E., \& Wallace, R. O. (1990). Financial disclosure regulation and its environment: A review and further analysis. Journal of Accounting and Public Policy, 9(2), 79-110.

Cumming, D., \& Walz, U. (2010). Private equity returns and disclosure around the world. Journal of International Business Studies, 41(4), 727-754.

Damodaran, A. (2005). The value of synergy. Available at SSRN 841486.

DeAngelo, L. E. (1981). Auditor size and audit quality. Journal of accounting and economics, 3(3), 183-199.

DeFond, M., \& Zhang, J. (2014). A review of archival auditing research. Journal of accounting and economics, 58(2-3), 275-326.

Dittmar, A., and J. Mahrt-Smith. 2007. Corporate governance and the value of cash holdings. Journal of Financial Economics 83: 599-634.

Dittmar, A., Mahrt-Smith, J., and H. Servaes. 2003. International corporate governance and 
corporate cash holdings. Journal of Financial and Quantitative Analysis 38: 111-133.

Dye, Ronald A. "Auditing standards, legal liability, and auditor wealth." Journal of political Economy 101, no. 5 (1993): 887-914.

Faleye, O. (2004). Cash and corporate control. The Journal of Finance, 59(5), 2041-2060.

Fargher, N., Taylor, M. H., \& Simon, D. T. (2001). The demand for auditor reputation across international markets for audit services. The International Journal of Accounting, 36(4), 407-421.

Faulkender, M., and R. Wang. 2006. Corporate financial policy and the value of cash. Journal of Finance 61: 1957-1990.

Glaeser, E. L., La Porta, R., Lopez-de-Silanes, F., \& Shleifer, A. (2004). Do institutions cause growth?. Journal of economic Growth, 9(3), 271-303.

Gleason, K. C., Greiner, A. J., \& Kannan, Y. H. (2017). Auditor pricing of excess cash holdings. Journal of Accounting, Auditing \& Finance, 32(3), 423-443.

Glover, S. M., D. F. Prawitt, J. J. Schultz, and M. F. Zimbelman. 2003. A test of changes in auditors' fraud-related planning judgments since the issuance of SAS no. 82. Auditing: A Journal of Practice \& Theory 22 (2): 237-251.

Gompers, P. A., Ishii, J. L., \& Metrick, A. (2001). Corporate governance and equity prices (No. w8449). National bureau of economic research.

Graham, John Robert and Leary, Mark T., The Evolution of Corporate Cash (Fall 2018). Journal of Applied Corporate Finance, Vol. 30, Issue 4, pp. 36-60, 2018. Available at

SSRN: https://ssrn.com/abstract=3335333 or http://dx.doi.org/10.1111/jacf.12316

Griffin, P. A., Lont, D. H., \& Sun, Y. (2009). Governance regulatory changes, International Financial Reporting Standards adoption, and New Zealand audit and non-audit fees: empirical evidence. Accounting \& Finance, 49(4), 697-724.

Gao, H., Harford, J., \& Li, K. (2013). Determinants of corporate cash policy: Insights from private firms. Journal of Financial Economics, 109(3), 623-639.

Gul, F.A., Tsui, J.S.L., Chen, C.J.P., 1998. Agency Costs and Audit Pricing: Evidence on Discretionary Accruals (Working Paper).

Gul, F.A.and J.S.L. Tsui. 2001. Free cash flow, debt monitoring, and audit pricing: further evidence on the role of director equity ownership

Auditing: A Journal of Practice and Theory, 20, pp. 72-84

Han, S., and J. Qiu. 2007. Corporate precautionary cash holdings. Journal of Corporate Finance $13(1): 43-57$. 
Harford, J. 1999. Corporate cash reserves and acquisitions. Journal of Finance 54: 1969-1997.

Harford, J., S.A. Mansi, and W.F. Maxwell. 2008. Corporate governance and firm cash holdings. Journal of Financial Economics 87(3): 535-555.

Harford, J., C. Wang, and K. Zhang. 2017. Foreign cash: Taxes, internal capital markets, and agency problems. Review of Financial Studies 30:1490-1538.

Hay, David, W. Robert Knechel, and Helen Ling. "Evidence on the impact of internal control and corporate governance on audit fees." International Journal of Auditing 12, no. 1 (2008): 924.

Houston, R.W., M. F. Peters, and J. H. Pratt. 1999. The audit risk model, business risk and auditplanning decisions. The Accounting Review 74 (3): 281-298.

Houston, R.W., M. F. Peters, and J. H. Pratt. 2005. Nonlitigation risk and pricing audit services. Auditing: A Journal of Practice \& Theory 24 (1): 37-53.

Huang, P., \& Zhang, Y. (2012). Does Enhanced Disclosure Really Reduce Agency Costs? Evidence from the Diversion of Corporate Resources. The Accounting Review, 87(1), 199-229.

Jandik, T., \& Kali, R. (2009). Legal systems, information asymmetry, and firm boundaries: Cross-border choices to diversify through mergers, joint ventures, or strategic alliances. Journal of International Business Studies, 40(4), 578-599.

Johnstone, K. M. 2000. Client acceptance decisions: Simultaneous effects of client business risk, audit risk, auditor business risk, and risk adaptation. Auditing: A Journal of Practice \& Theory 19 (1): 1-25.

Kalcheva, I., and K. V. Lins. 2007. International evidence on cash holdings and expected managerial agency problems. Review of Financial Studies 20 (4): 1087-1112.

Keynes, J. 1936. The General Theory of Employment, Interest and Money. New York: Harcourt, Brace.

Khanna T, Yafeh Y (2005) Business groups and risk sharing around the world. J. Bus. 78(1):301-340.

Kwok, C. C., \& Tadesse, S. (2006). National culture and financial systems.Journal of International Business Studies, 37(2), 227-247.

La Porta, R. Lopez-de-Silanes, F., Shleifer, A. and Vishny, R. 1998. Law and finance. Journal of Political Economy, 106(6).

La Porta, Rafael, Florencio Lopez-de-Silanes, and Andrei Shleifer. 2006. "What works in securities laws?." The Journal of Finance 61, no. 1:1-32. 
Larcker, David F., and Scott A. Richardson. 2004. "Fees paid to audit firms, accrual choices, and corporate governance." Journal of accounting research 42, no. 3 :625-658.

Sarens, G., Lenz, R., and Decaux, L. 2016. Insights Into Self-Images of Internal Auditors. The EDP Audit, Control, and Security Newsletter, 54(4), online

Leuz, C., Nanda, D. and Wysocki, P.D. 2003. Earnings management and investor protection: an international comparison. Journal of Financial Economics 69: 505-527.

Lyon, J. D., and M. W. Maher. 2005. The importance of business risk in setting audit fees: Evidence from cases of client misconduct. Journal of Accounting Research 43 (1): 133-151.

Marshall, M. G., \& Jaggers, K. (2000). "Polity IV project" Center for International Development and Conflict Management, University of Maryland.

Masulis, R., C. Wang, and F. Xie. 2007. Corporate governance and acquirer returns. Journal of Finance 62: 1851-1889.

Menon, K., and D. O. Williams. 1994. The insurance hypothesis and market prices. The Accounting Review 69 (2): 327-342.

Mikkelson, W., and M. Partch. 2003. Do persistent large cash reserves hinder performance? Journal of Financial and Quantitative Analysis 38: 275-294.

Myers, S., and N. Majluf. 1984. Corporate financing and investment decisions when firms have information that investors do not have. Journal of Financial Economics 13: 187-221.

Myers, S.C., and R. G. Rajan. 1995. The paradox of liquidity. Quarterly Journal of Economics 113: 733-771.

Opler, T., L. Pinkowitz, R. Stulz, and R. Williamson. 1999. The determinants and implications of corporate cash holdings. Journal of Finance 52: 3-46.

Pagano, M., Randl, O., Röell, A. A., \& Zechner, J. (2001). What makes stock exchanges succeed? Evidence from cross-listing decisions. European Economic Review, 45(4), 770-782.

Palmrose, Z. V. (1997). Who got sued?. Journal of Accountancy, 183(3), 67.

Pinkowitz, L., Stultz, R. \& Williamson, R., 2006. Does the contribution of corporate cash holdings and dividends to firm value depend on governance? a cross-country analysis. The Journal of Finance 61(6): 2725-2751. 
Piot, Charles. "Auditor reputation and model of governance: a comparison of France, Germany and Canada." International Journal of Auditing 9, no. 1 (2005): 21-44.

Riddick, L. A., \& Whited, T. M. (2009). The corporate propensity to save. The Journal of Finance, 64(4), 1729-1766.

Seetharaman, A., Gul, F. A., \& Lynn, S. G. (2002). Litigation risk and audit fees: Evidence from UK firms cross-listed on US markets. Journal of accounting and economics, 33(1), 91-115.

Simunic, D. 1980. The pricing of audit services: theory and evidence. Journal of Accounting Research. 18(1): 161-190.

Stanley, J. D., 2011. Is the audit fee disclosure a leading indicator of clients' business risk? Auditing: A Journal of Practice and Theory, 30 (3), 157-179.

Taylor, M. H., \& Simon, D. T. (1999). Determinants of audit fees: the importance of litigation, disclosure, and regulatory burdens in audit engagements in 20 countries. The International Journal of Accounting, 34(3), 375-388.

Venkataraman, R., J. Weber, and M. Willenborg (2008) Litigation Risk, Audit Quality, and Audit Fees: Evidence from Initial Public Offerings. The Accounting Review: September 2008, Vol. 83, No. 5, pp. 1315-1345.

Watts, R. L. (1977). Corporate financial statements, a product of the market and political processes. Australian journal of management, 2(1), 53-75.

Watts, R., \& Zimmerman, J. (1981). The markets for independence and independent auditors.

Wingate, M. L. "An international examination of country-specific determinants of audit fees." (1995): 3562-3562.

Wynn, J. P. (2008). Legal liability coverage and voluntary disclosure. The Accounting Review, 83(6), 1639-1669.

Wysocki, Peter D. "Discussion of ultimate ownership, income management, and legal and extralegal institutions." Journal of Accounting Research 42, no. 2 (2004): 463-474.

Zimbelman, M. F. 1997. The effect of SAS No. 82 on auditors' attention to fraud risk factors and audit planning decisions. Journal of Accounting Research 35 (supplement): 75-97.

Zhang, J. Z. and Y. Yu. 2016. Does Board Independence Affect Audit Fees? Evidence from Recent Regulatory Reforms. European Accounting Review 25 (4): 793-814. 


\section{Appendix 1: Definitions of Variables}

Panel A: Dependent and treatment variable definitions

\begin{tabular}{|c|c|}
\hline VARIABLE & DEFINITION \\
\hline LAF & $\begin{array}{l}\text { The firm natural logarithm of the audit fees (AUDIT_FEES) at fiscal year-end, from } \\
\text { AuditAnalytics. }\end{array}$ \\
\hline \multicolumn{2}{|c|}{ Treatment Variables } \\
\hline \multicolumn{2}{|c|}{ Cash Holding Variables } \\
\hline XSCASH & $\begin{array}{l}\text { The firm's residual from the optimal cash holding model scaled by total assets at fiscal year- } \\
\text { end. }\end{array}$ \\
\hline
\end{tabular}

Disclosure

CIFAR

\section{Enforcement}

EFF_JUD

RuleLaw_2000

CRIM_ACC

CRIMINAL

\section{Accountant Liability}

Disclosure requirements index which equals the arithmetic mean of: (1) Prospect; (2) Compensation; (3) Shareholders; (4) Inside ownership; (5) Contracts Irregular; (6) and Transactions. La Porta et al. 2006

Assessment of the "efficiency and integrity of the legal environment as it affects business, particularly foreign firms" produced by the country-risk rating agency Business International Corporation. It "may be taken to represent investors' assessments of conditions in the country in question." Average between 1980-1983. Scale from 0 to 10 with higher scores indicating higher efficiency levels.

Rule of law measures the extent to which agents have confidence in and abide by the rules of society in year 2000. These include perceptions of the incidence of both violent and nonviolent crime, the effectiveness and predictability of the judiciary, and the enforceability of contracts. The source for the data on rule of law is Kaufmann, Daniel, Aart Kraay and Massimo Mastruzzi. 2003. "Governance Matters III: Updated Governance Indicators for 1996-02." Working Paper Draft for comments. Washington, D.C.: World Bank.

BURDEN financial information accompanying the prospectus. Equals one when investors are not required to prove the accountant was negligent. Equals zero when investors must also prove that the Accountant acted with negligence or gross negligence, or restitution from the accountant is unavailable. La Porta et al. (2006).

An index of criminal sanctions applicable to the Accountant (or its officers) when the financial statements accompanying the prospectus omit material information. A higher number means it is easier to hold the accountant criminally liable. Equals zero if the Accountant cannot be held criminally liable when the financial statements accompanying the prospectus are misleading. Equals one-half if the Accountant can be held criminally liable when aware that the financial statements accompanying the prospectus are misleading. Equals one if the Accountant can also be held criminally liable when negligently unaware that the financial statements accompanying the prospectus are misleading. La Porta et al. (2006).

The index of criminal sanctions equals the arithmetic mean of liability for: (1) Criminal director (and key officers); (2) Criminal distributor (underwriter and key officers); and (3) Criminal accountant (and key officers). 
ORD_ACC

LIAB_SCORE

Shareholder Rights

ANTIDIR

XCONST

1SHARE_1VOTE

SH_SCORE
An index aggregating stop and do orders that may be directed to the Accountant in case of a defective prospectus. A higher number means that the accountant may be ordered to refrain from the most types of action. The index is formed by averaging the sub-indexes of orders to stop and to do. The sub-index of orders to stop equals one if the Accountant may be ordered to refrain from a broad range of actions; equals one-half if the Accountant may only be ordered to desist from limited actions; equals zero otherwise. The sub-index of orders to do equals one if the Accountant may be ordered to perform a broad range of actions to rectify the violation; equals one-half if the Accountant may only be ordered to perform limited actions; equals zero otherwise. We disregard orders that may be issued by Courts at the request of a private party in a civil lawsuit.

A principal component factor score of BURDEN, ORD_ACC CRIM_ACC and CRIMINAL.

An index aggregating the shareholder rights which we labeled as "anti-director rights." The index is formed by adding 1 when: (1) the country allows shareholders to mail their proxy vote; (20 shareholders are not required to deposit their shares prior to the General Shareholders' Meeting; (3) cumulative voting is allowed; (4) an oppressed minorities mechanism is in place; or (5) when the minimum percentage of share capital that entitles a shareholder to call for an Extraordinary Shareholders' Meeting is less than or equal to $10 \%$ (the sample median). The index ranges from 0 to 5 , with higher values indicating more shareholder rights.

Executive Constraints A measure of the extent of institutionalized constraints on the decision making powers of chief executives. The variable takes seven different values: (1) Unlimited authority (there are no regular limitations on the executive's actions, as distinct from irregular limitations such as the threat or actuality of coups and assassinations); (2) Intermediate category; (3) Slight to moderate limitation on executive authority (there are some real but limited restraints on the executive); (4) Intermediate category; (5) Substantial limitations on executive authority (the executive has more effective authority than any accountability group but is subject to substantial constraints by them); (6) Intermediate category; (7) Executive parity or subordination (accountability groups have effective authority equal to or greater than the executive in most areas of activity). This variable ranges from one to seven where higher values equal a greater extent of institutionalized constraints on the power of chief executives. This variable is calculated as the average from 1960 through 2001. Source: Jaggers and Marshall (2000); Glaeser, La Porta, Lopez-deSilanes, and Shleifer (2004).

Equals one if the Company Law or Commercial Code of the country requires that ordinary shares carry one vote per share, and zero otherwise.

A principal component factor score of ANTIDIR, XCONST and ISHARE_IVOTE.

Panel B: Audit fee control variable definitions

\begin{tabular}{|c|c|}
\hline Variable & Definition \\
\hline LNTA & The natural logarithm of total assets (AT) at fiscal year-end (in $\$$ millions), from Compustat. \\
\hline INVREC & $\begin{array}{l}\text { Inventory plus accounts receivable, divided by total assets }[(\mathrm{RECT}+\mathrm{INVT}) / \mathrm{AT}] \text { at fiscal } \\
\text { year-end, from Compustat. }\end{array}$ \\
\hline FOREIGN & $\begin{array}{l}1 \text { if firm has foreign exchange gain or loss (FCA) at the end of the current fiscal year, and } 0 \\
\text { otherwise, from Compustat. }\end{array}$ \\
\hline MA & 1 if firm had a merger during current fiscal-year, and 0 otherwise. \\
\hline
\end{tabular}


QRATIO Hogan: The ratio of current assets minus inventory to total current liabilities [(ACTINVT)/LCT] at current fiscal year end, from Compustat.

ROA Return on assets, defined as the ratio of operating income (OIADP) to fiscal year-end total assets (AT) at fiscal year end, from Compustat.

LOSS 1 if firm i reports negative net income (NI) in current or prior fiscal year, and 0 otherwise, from Compustat.

LEV the ratio of the sum of debt in current liabilities and long-term debt to total assets [DLC+DLTT)/AT] at current fiscal year end, from Compustat.

GROWTH The percentage change in sales (SALE) between current and prior fiscal years, from Compustat.

MKTB The market value of the firm computed as the product of the fiscal year end share price and the number of shares outstanding at year end, divided by total assets at the end of the fiscal year $\left(\mathrm{PRCC} \_\mathrm{F} * \mathrm{CSHO}\right) / \mathrm{AT}$.

RESTATE $\quad 1$ if a firm announced a restatement during the year, and 0 otherwise, from AuditAnalytics. XDOPS 1 if firm reported extraordinary items or discontinued operations (XIDO) in the current fiscal year, and 0 otherwise, from Compustat.

BUSY $\quad 1$ if firm had fiscal year end $12 / 31$, and 0 otherwise.

BIGN $\quad 1$ if auditor is a Big $\mathrm{N}$ auditor, and 0 otherwise, from AuditAnalytics.

INITIAL 1 if the auditor is in the first or second year of an audit engagement in the current fiscal year, and 0 otherwise, from AuditAnalytics.

GC 1 if firm was issued a modified auditor going concern opinion in current fiscal year, and 0 otherwise, from Audit Analytics.

ICFR 1 if firm received an audit opinion on internal controls over its financial (IC_IS_EFFECTIVE) in the current fiscal year, and 0 otherwise, from AuditAnalytics.

ICWEAK 1 if firm auditors identify a material weakness in internal control in current fiscal year, and 0 otherwise, from AuditAnalytics.

USAUDITOR 1 if firm engages a U.S. auditor, and 0 otherwise.

GDPPC GDP per capita is gross domestic product divided by midyear population in U.S. dollars from the World Bank Group.

Instruments

CIV_COM

LGDP

Equal to 1 if the home country has Civil law origin and equal to 0 for Common law. Natural log of the home country's gross domestic product per capita in current US dollars, obtained from the World Bank Group

ADRFIRM Equal to 1 if the ADR ratio (ADRR in Compustat) is greater than zero. 
Table 1: Sample Distribution

Panel A: Distribution by Year

\begin{tabular}{rrr}
\hline Year & Number & Percent \\
\hline 2002 & 426 & 7.33 \\
2003 & 469 & 8.08 \\
2004 & 471 & 8.11 \\
2005 & 446 & 7.68 \\
2006 & 420 & 7.23 \\
2007 & 381 & 6.56 \\
2008 & 354 & 6.10 \\
2009 & 340 & 5.85 \\
2010 & 336 & 5.79 \\
2011 & 345 & 5.94 \\
2012 & 338 & 5.82 \\
2013 & 363 & 6.25 \\
2014 & 368 & 6.34 \\
2015 & 374 & 6.44 \\
2016 & 377 & 6.49 \\
\hline Total & 5,808 & 100.00
\end{tabular}

\section{Panel B: Distribution by SIC Code}

\begin{tabular}{lrr}
\hline SIC & Number & Percent \\
\hline $00-09$ & 30 & 0.51 \\
$10-19$ & 1,281 & 22.57 \\
$20-29$ & 1,472 & 25.34 \\
$30-39$ & 1,680 & 28.93 \\
$40-43$ & 47 & 0.82 \\
$50-59$ & 232 & 3.99 \\
$70-79$ & 922 & 15.88 \\
$80-89$ & 105 & 1.81 \\
$90-99$ & 39 & 0.76 \\
\hline Total & 5,808 & 100.00
\end{tabular}

Panel C: Distribution by Country

\begin{tabular}{lrrlrr}
\hline Country & Number & Percent & Country & Number & Percent \\
\hline ARG & 35 & 0.60 & IND & 90 & 1.55 \\
AUS & 111 & 1.91 & IRL & 264 & 4.55 \\
BEL & 28 & 0.48 & ISR & 874 & 15.05 \\
BRA & 178 & 3.06 & ITA & 63 & 1.08 \\
CAN & 2,347 & 40.41 & JPN & 213 & 3.67 \\
CHE & 134 & 2.31 & MEX & 116 & 2.00 \\
CHL & 91 & 1.57 & NLD & 288 & 4.96 \\
COL & 9 & 0.15 & NOR & 35 & 0.60 \\
DEU & 116 & 2.00 & NZL & 2 & 0.03 \\
DNK & 16 & 0.28 & PHL & 7 & 0.12 \\
ESP & 14 & 0.24 & SGP & 60 & 1.03 \\
FIN & 27 & 0.46 & SWE & 36 & 0.62 \\
FRA & 158 & 2.72 & ZAF & 91 & 1.57 \\
GBR & 405 & 6.97 & Total & 5,808 & 100 \\
\hline
\end{tabular}


Table 2: Descriptive Statistics

\begin{tabular}{|c|c|c|c|c|c|c|}
\hline Variable & $\mathrm{N}$ & Mean & Std. Dev. & $\mathrm{Q} 1$ & Median & $\mathrm{Q} 3$ \\
\hline \multicolumn{7}{|c|}{ DEPENDENT VARIABLE } \\
\hline AUDIT_FEES (\$000) & 5,808 & 3,639 & 7,932 & 246 & 854 & 3,019 \\
\hline LNAF & 5,808 & 13.702 & 1.664 & 12.417 & 13.659 & 14.921 \\
\hline \multicolumn{7}{|c|}{ TREATMENT VARIABLES } \\
\hline $\begin{array}{l}\text { Excess Cash } \\
\text { XSCASH } \\
\text { Disclosure }\end{array}$ & 5,808 & 0.419 & 1.853 & -0.197 & 0.768 & 1.499 \\
\hline $\begin{array}{l}\text { CIFAR } \\
\text { Enforcement }\end{array}$ & 5,808 & 74.896 & 5.447 & 74.000 & 75.000 & 75.000 \\
\hline EFF_JUD & 5,808 & 9.1374 & 1.1308 & 9.2500 & 9.2500 & 10.0000 \\
\hline $\begin{array}{l}\text { RuleLaw_2000 } \\
\text { Auditor Liability }\end{array}$ & 5,808 & 1.627 & 0.637 & 1.080 & 1.970 & 2.010 \\
\hline BURDEN_ACC & 5,808 & 0.763 & 0.253 & 0.660 & 0.660 & 1.000 \\
\hline ORD_ACC & 5,818 & 0.712 & 0.441 & 0 & 1.000 & 1.000 \\
\hline CRIM_ACC & 5,808 & 0.705 & 0.314 & 0.500 & 0.500 & 1.000 \\
\hline $\begin{array}{l}\text { CRIMINAL } \\
\text { Shareholder's Rig }\end{array}$ & 5,808 & 0.6277 & 0.2345 & 0.5000 & 0.8333 & 0.8333 \\
\hline ANTIDIR & 5,808 & 3.9762 & 1.2563 & 3.0000 & 5.0000 & 5.0000 \\
\hline XCONST & 5,808 & 6.648 & 1.002 & 7.000 & 7.000 & 7.000 \\
\hline 1SHARE_1VOTE & 5,808 & 0.907 & 0.291 & 1.000 & 1.000 & 1.000 \\
\hline \multicolumn{7}{|c|}{ CONTROL VARIABLES } \\
\hline AT $(\$ 000)$ & 5,808 & 12,086 & 36,319 & 118 & 1,053 & 7,435 \\
\hline LNTA & 5,808 & 6.814 & 2.580 & 4.772 & 6.960 & 8.914 \\
\hline INVREC & 5,808 & 0.216 & 0.155 & 0.091 & 0.193 & 0.303 \\
\hline FOREIGN & 5,808 & 0.752 & 0.432 & 1.000 & 1.000 & 1.000 \\
\hline MA & 5,808 & 0.445 & 0.497 & 0.000 & 0.000 & 1.000 \\
\hline QRATIO & 5,808 & 0.923 & 2.091 & 0.094 & 0.257 & 0.816 \\
\hline ROA & 5,808 & -0.045 & 0.309 & -0.068 & 0.028 & 0.081 \\
\hline LOSS & 5,808 & 0.377 & 0.485 & 0.000 & 0.000 & 1.000 \\
\hline LEV & 5,808 & 0.244 & 0.278 & 0.029 & 0.201 & 0.343 \\
\hline GROWTH & 5,808 & 0.255 & 0.976 & -0.062 & 0.082 & 0.263 \\
\hline MTB & 5,808 & 3.498 & 5.720 & 1.267 & 1.804 & 3.084 \\
\hline RESTATE & 5,808 & 0.051 & 0.221 & 0.000 & 0.000 & 0.000 \\
\hline XDOPS & 5,808 & 0.157 & 0.364 & 0.000 & 0.000 & 0.000 \\
\hline BUSY & 5,808 & 0.762 & 0.426 & 1.000 & 1.000 & 1.000 \\
\hline BIGN & 5,808 & 0.860 & 0.347 & 1.000 & 1.000 & 1.000 \\
\hline INITIAL & 5,808 & 0.141 & 0.348 & 0.000 & 0.000 & 0.000 \\
\hline $\mathrm{GC}$ & 5,808 & 0.053 & 0.224 & 0.000 & 0.000 & 0.000 \\
\hline ICFR & 5,808 & 0.638 & 0.481 & 0.000 & 1.000 & 1.000 \\
\hline ICWEAK & 5,808 & 0.048 & 0.213 & 0.000 & 0.000 & 0.000 \\
\hline USAUDITOR & 5,808 & 0.125 & 0.331 & 0.000 & 0.000 & 0.000 \\
\hline GDPPC & 5,808 & 0.037 & 0.014 & 0.028 & 0.040 & 0.047 \\
\hline
\end{tabular}




\section{Table 3 Excess Cash and Audit Fees}

This table shows the test of hypothesis 2 using regression results for Equation 2 with dependent variable, LnFee, the natural $\log$ of audit fees. The sample is 5,808 foreign incorporated firms traded publicly in the US between 2001 and 2016. The regression is estimated using OLS with errors clustered by firm. Fixed effects are included for years and Fama French industries. Significance is indicated at $99^{\text {th }}, 95^{\text {th }}$ and $90^{\text {th }}$ percentile with $* * *, * *$, and $*$, respectively.

\begin{tabular}{|c|c|c|c|c|c|c|}
\hline Variable & Est. & $p$-value & & Est. & $p$-value & \\
\hline Intercept & 6.258 & 0.000 & $* * *$ & 6.306 & 0.000 & $* * *$ \\
\hline XSCASH & 0.068 & 0.000 & $* * *$ & & & \\
\hline XSCASHPOS & & & & 0.092 & 0.001 & $* * *$ \\
\hline LNTA & 0.562 & 0.000 & $* * *$ & 0.565 & 0.000 & $* * *$ \\
\hline INVREC & 1.036 & 0.000 & $* * *$ & 1.043 & 0.000 & $* * *$ \\
\hline FOREIGN & 0.028 & 0.474 & & 0.040 & 0.307 & \\
\hline MA & 0.140 & 0.000 & $* * *$ & 0.135 & 0.000 & $* * *$ \\
\hline QRATIO & -0.044 & 0.000 & $* * *$ & -0.040 & 0.000 & $* * *$ \\
\hline ROA & -0.298 & 0.000 & $* * *$ & -0.296 & 0.000 & $* * *$ \\
\hline LOSS & 0.087 & 0.002 & $* * *$ & 0.083 & 0.003 & $* * *$ \\
\hline LEV & 0.034 & 0.525 & & 0.030 & 0.583 & \\
\hline GROWTH & -0.041 & 0.000 & $* * *$ & -0.039 & 0.000 & $* * *$ \\
\hline MTB & 0.008 & 0.012 & $* *$ & 0.008 & 0.015 & $* *$ \\
\hline RESTATE & 0.004 & 0.911 & & 0.004 & 0.909 & \\
\hline XDOPS & 0.189 & 0.000 & $* * *$ & 0.195 & 0.000 & $* * *$ \\
\hline BUSY & -0.172 & 0.000 & $* * *$ & -0.170 & 0.000 & $* * *$ \\
\hline INITIAL & -0.122 & 0.000 & $* * *$ & -0.126 & 0.000 & $* * *$ \\
\hline GC & 0.162 & 0.003 & $* * *$ & 0.142 & 0.010 & $* *$ \\
\hline ICFR & 0.173 & 0.000 & $* * *$ & 0.176 & 0.000 & $* * *$ \\
\hline ICWEAK & 0.318 & 0.000 & $* * *$ & 0.322 & 0.000 & $* * *$ \\
\hline BIGN & 0.170 & 0.000 & $* * *$ & 0.175 & 0.000 & $* * *$ \\
\hline USAUDITOR & 0.328 & 0.000 & $* * *$ & 0.346 & 0.000 & $* * *$ \\
\hline LGDP & 0.267 & 0.000 & $* * *$ & 0.255 & 0.000 & $* * *$ \\
\hline R-Square & 0.874 & & & 0.872 & & \\
\hline Obs. & 5,808 & & & 5,808 & & \\
\hline
\end{tabular}




\section{Table 4 The Effects of Higher Accounting Disclosures and Excess Cash Holdings for Firms Cross-Listed in the US}

This table shows the test of hypothesis 2 using regression results for Equation 2 with dependent variable, LnFee, the natural $\log$ of audit fees. The sample is 5,808 foreign incorporated firms traded publicly in the US between 2001 and 2016. The regression is estimated using 2SLS methodology. Instruments are Civ_Com (equal to 1 for Civil, 0 for Common law), LGDP (natural log of GDP per capita in the home country), and ADRFirm (equal to 1 if the firm has an ADR ratio greater than zero). Fixed effects are included for years and Fama French industries. Significance is indicated at $99^{\text {th }}, 95^{\text {th }}$ and $90^{\text {th }}$ percentile with $* * *, * *$, and $*$, respectively.

\begin{tabular}{|c|c|c|c|}
\hline Variable & Est. & $p$-value & \\
\hline Intercept & 5.272 & 0.000 & $* * *$ \\
\hline XSCASH & 0.051 & 0.000 & $* * *$ \\
\hline CIFAR & 0.027 & 0.000 & $* * *$ \\
\hline CIFARXCASH & 0.004 & 0.000 & $* * *$ \\
\hline LNTA & 0.530 & 0.000 & $* * *$ \\
\hline INVREC & 0.934 & 0.000 & $* * *$ \\
\hline FOREIGN & 0.032 & 0.192 & \\
\hline MA & 0.140 & 0.000 & $* * *$ \\
\hline QRATIO & -0.041 & 0.000 & $* * *$ \\
\hline ROA & -0.263 & 0.000 & $* * *$ \\
\hline LOSS & 0.081 & 0.002 & $* * *$ \\
\hline LEV & 0.055 & 0.171 & \\
\hline GROWTH & -0.037 & 0.001 & $* * *$ \\
\hline MTB & 0.008 & 0.001 & $* * *$ \\
\hline RESTATE & 0.032 & 0.478 & \\
\hline XDOPS & 0.206 & 0.000 & $* * *$ \\
\hline BUSY & -0.135 & 0.000 & $* * *$ \\
\hline INITIAL & -0.141 & 0.000 & $* * *$ \\
\hline $\mathrm{GC}$ & 0.131 & 0.009 & $* * *$ \\
\hline ICFR & 0.191 & 0.000 & $* * *$ \\
\hline ICWEAK & 0.304 & 0.000 & $* * *$ \\
\hline BIGN & 0.170 & 0.000 & $* * *$ \\
\hline USAUDITOR & 0.430 & 0.000 & $* * *$ \\
\hline LGDP & 0.180 & 0.000 & $* * *$ \\
\hline
\end{tabular}

Adj R-Sq $\quad 0.813$

Obs. $\quad 5,808$ 


\section{Table 5 The Effects of Stronger Legal Enforcement and Excess Cash Holdings for Firms}

Cross-Listed in the US

This table shows the test of hypothesis 3 using regression results for Equation 3 with dependent variable, LnFee, the natural $\log$ of audit fees. The sample is 5,808 foreign incorporated firms traded publicly in the US between 2001 and 2016. The regression is estimated using 2SLS methodology. Instruments are Civ_Com (equal to 1 for Civil, 0 for Common law), LGDP (natural log of GDP per capita in the home country), and ADRFirm (equal to 1 if the firm has an ADR ratio greater than zero). Fixed effects are included for years and Fama French industries. Significance is indicated at $99^{\text {th }}, 95^{\text {th }}$ and $90^{\text {th }}$ percentile with $* * * * *$, and $*$, respectively.

\begin{tabular}{|c|c|c|c|c|c|c|}
\hline \multirow[b]{2}{*}{ Variable } & \multicolumn{2}{|c|}{$\begin{array}{c}\text { Model 1 } \\
\text { EFF_JUD }\end{array}$} & \multicolumn{4}{|c|}{$\begin{array}{c}\text { Model } 2 \\
\text { RULELAW }\end{array}$} \\
\hline & Est. & $p$-value & & Est. & $p$-value & \\
\hline Intercept & 7.797 & 0.000 & $* * *$ & 20.388 & 0.000 & $* * *$ \\
\hline XSCASH & 0.051 & 0.000 & $* * *$ & 0.051 & 0.000 & $* * *$ \\
\hline EFF_JUD & 0.546 & 0.000 & $* * *$ & & & \\
\hline EFF_JUDXCASH & 0.050 & 0.000 & $* * *$ & & & \\
\hline RULELAW & & & & 1.770 & 0.000 & $* * *$ \\
\hline RULELAWXCASH & & & & 0.234 & 0.000 & $* * *$ \\
\hline LNTA & 0.530 & 0.000 & $* * *$ & 0.530 & 0.000 & $* * *$ \\
\hline INVREC & 0.934 & 0.000 & $* * *$ & 0.934 & 0.000 & $* * *$ \\
\hline FOREIGN & 0.032 & 0.400 & & 0.032 & 0.398 & \\
\hline MA & 0.140 & 0.000 & $* * *$ & 0.140 & 0.000 & $* * *$ \\
\hline QRATIO & -0.041 & 0.000 & $* * *$ & -0.041 & 0.000 & $* * *$ \\
\hline ROA & -0.263 & 0.000 & $* * *$ & -0.263 & 0.000 & $* * *$ \\
\hline LOSS & 0.081 & 0.050 & $* *$ & 0.081 & 0.049 & $* *$ \\
\hline LEV & 0.055 & 0.377 & & 0.055 & 0.375 & \\
\hline GROWTH & -0.037 & 0.024 & $* *$ & -0.037 & 0.023 & $* *$ \\
\hline MTB & 0.008 & 0.033 & $* *$ & 0.008 & 0.032 & $* *$ \\
\hline RESTATE & 0.032 & 0.647 & & 0.032 & 0.646 & \\
\hline XDOPS & 0.206 & 0.000 & $* * *$ & 0.206 & 0.000 & $* * *$ \\
\hline BUSY & -0.135 & 0.001 & $* * *$ & -0.135 & 0.001 & $* * *$ \\
\hline INITIAL & -0.141 & 0.005 & $* * *$ & -0.141 & 0.005 & $* * *$ \\
\hline GC & 0.131 & 0.090 & $*$ & 0.131 & 0.088 & $*$ \\
\hline ICFR & 0.191 & 0.003 & $* * *$ & 0.191 & 0.003 & $* * *$ \\
\hline ICWEAK & 0.304 & 0.000 & $* * *$ & 0.304 & 0.000 & $* * *$ \\
\hline BIGN & 0.170 & 0.001 & $* * *$ & 0.170 & 0.001 & $* * *$ \\
\hline USAUDITOR & 0.430 & 0.000 & $* * *$ & 0.430 & 0.000 & $* * *$ \\
\hline LGDP & -0.354 & 0.045 & $* *$ & -1.357 & 0.002 & $* * *$ \\
\hline Adj R-Sq & 0.644 & & & 0.646 & & \\
\hline Obs. & 5,808 & & & 5,808 & & \\
\hline
\end{tabular}




\section{Table 6. The effects of higher home country liability and excess cash holdings for firms cross-listed in the US}

This table shows the test of hypothesis 4 using regression results for Equation 4 with dependent variable, LnFee, the natural log of audit fees. The sample is 5,808 foreign incorporated firms traded publicly in the US between 2001 and 2016. The regression is estimated using 2SLS methodology. Instruments are Civ_Com (equal to 1 for Civil, 0 for Common law), LGDP (natural log of GDP per capita in the home country), and ADRFirm (equal to 1 if the firm has an ADR ratio greater than zero). Fixed effects are included for years and Fama French industries. Significance is indicated at $99^{\text {th }}, 95^{\text {th }}$ and $90^{\text {th }}$ percentile with $* * *, * *$ and $*$, respectively.

\begin{tabular}{|c|c|c|c|c|c|c|c|c|c|c|c|c|c|c|c|}
\hline \multirow[b]{2}{*}{ Variable } & \multicolumn{2}{|c|}{$\begin{array}{c}\text { Model } 1 \\
\text { BURDEN }\end{array}$} & & \multicolumn{2}{|c|}{$\begin{array}{c}\text { Model } 2 \\
\text { ORD_ACC }\end{array}$} & \multicolumn{4}{|c|}{$\begin{array}{c}\text { Model 3 } \\
\text { CRIM_ACC }\end{array}$} & \multicolumn{2}{|c|}{$\begin{array}{c}\text { Model } 4 \\
\text { CRIMINAL }\end{array}$} & \multicolumn{4}{|c|}{$\begin{array}{c}\text { Model 5 } \\
\text { LIAB_Score }\end{array}$} \\
\hline & Est. & p-value & & Est. & p-value & & Est. & p-value & & Est. & p-value & & Est. & p-value & \\
\hline Intercept & 6.694 & 0.000 & $* * *$ & 5.083 & 0.000 & $* * *$ & 5.755 & 0.000 & $* * *$ & 5.138 & 0.000 & $* * *$ & 2.140 & 0.034 & $* *$ \\
\hline XSCASH & 0.051 & 0.000 & $* * *$ & 0.051 & 0.000 & $* * *$ & 0.051 & 0.000 & $* * *$ & 0.051 & 0.000 & $* * *$ & 0.051 & 0.001 & $* * *$ \\
\hline BURDEN & 0.247 & 0.056 & $*$ & & & & & & & & & & & & \\
\hline BURDENXCASH & 0.515 & 0.000 & $* * *$ & & & & & & & & & & & & \\
\hline ORD_ACC & & & & -0.076 & 0.315 & & & & & & & & & & \\
\hline ORD_ACCXCASH & & & & 0.581 & 0.000 & $* * *$ & & & & & & & & & \\
\hline CRIM_ACC & & & & & & & 0.276 & 0.225 & & & & & & & \\
\hline CRIM_ACCXCASH & & & & & & & 0.729 & 0.000 & $* * *$ & & & & & & \\
\hline CRIMINAL & & & & & & & & & & 0.546 & 0.104 & & & & \\
\hline CRIMINALXCASH & & & & & & & & & & 0.892 & 0.000 & $* * *$ & & & \\
\hline LIAB_Score & & & & & & & & & & & & & -1.070 & 0.000 & $* * *$ \\
\hline LIAB_ScoreXCASH & & & & & & & & & & & & & 0.964 & 0.000 & $* * *$ \\
\hline LNTA & 0.530 & 0.000 & $* * *$ & 0.530 & 0.000 & $* * *$ & 0.530 & 0.000 & $* * *$ & 0.530 & 0.000 & $* * *$ & 0.530 & 0.000 & $* * *$ \\
\hline INVREC & 0.934 & 0.000 & $* * *$ & 0.934 & 0.000 & $* * *$ & 0.934 & 0.000 & $* * *$ & 0.934 & 0.000 & $* * *$ & 0.934 & 0.000 & $* * *$ \\
\hline FOREIGN & 0.032 & 0.370 & & 0.032 & 0.387 & & 0.032 & 0.457 & & 0.032 & 0.470 & & 0.032 & 0.580 & \\
\hline MA & 0.140 & 0.000 & $* * *$ & 0.140 & 0.000 & $* * *$ & 0.140 & 0.000 & $* * *$ & 0.140 & 0.001 & $* * *$ & 0.140 & 0.009 & $* * *$ \\
\hline QRATIO & -0.041 & 0.000 & $* * *$ & -0.041 & 0.000 & $* * *$ & -0.041 & 0.000 & $* * *$ & -0.041 & 0.000 & $* * *$ & -0.041 & 0.005 & $* * *$ \\
\hline $\mathrm{ROA}$ & -0.263 & 0.000 & $* * *$ & -0.263 & 0.000 & $* * *$ & -0.263 & 0.001 & $* * *$ & -0.263 & 0.001 & $* * *$ & -0.263 & 0.010 & $* * *$ \\
\hline LOSS & 0.081 & 0.036 & $* *$ & 0.081 & 0.044 & $* *$ & 0.081 & 0.083 & $*$ & 0.081 & 0.092 & $*$ & 0.081 & 0.197 & \\
\hline LEV & 0.055 & 0.346 & & 0.055 & 0.364 & & 0.055 & 0.435 & & 0.055 & 0.448 & & 0.055 & 0.561 & \\
\hline GROWTH & -0.037 & 0.016 & $* *$ & -0.037 & 0.020 & $* *$ & -0.037 & 0.046 & $* *$ & -0.037 & 0.052 & $*$ & -0.037 & 0.137 & \\
\hline МТB & 0.008 & 0.023 & $* *$ & 0.008 & 0.028 & $* *$ & 0.008 & 0.059 & $*$ & 0.008 & 0.067 & $*$ & 0.008 & 0.160 & \\
\hline RESTATE & 0.032 & 0.626 & & 0.032 & 0.638 & & 0.032 & 0.686 & & 0.032 & 0.694 & & 0.032 & 0.764 & \\
\hline XDOPS & 0.206 & 0.000 & $* * *$ & 0.206 & 0.000 & $* * *$ & 0.206 & 0.000 & $* * *$ & 0.206 & 0.000 & $* * *$ & 0.206 & 0.002 & $* * *$ \\
\hline BUSY & -0.135 & 0.000 & $* * *$ & -0.135 & 0.000 & $* * *$ & -0.135 & 0.002 & $* * *$ & -0.135 & 0.003 & $* * *$ & -0.135 & 0.022 & $* *$ \\
\hline INITIAL & -0.141 & 0.003 & $* * *$ & -0.141 & 0.004 & $* * *$ & -0.141 & 0.013 & $* *$ & -0.141 & 0.015 & $* *$ & -0.141 & 0.063 & $*$ \\
\hline GC & 0.131 & 0.070 & $*$ & 0.131 & 0.081 & $*$ & 0.131 & 0.134 & & 0.131 & 0.145 & & 0.131 & 0.264 & \\
\hline
\end{tabular}




\begin{tabular}{|c|c|c|c|c|c|c|c|c|c|c|c|c|c|c|c|}
\hline ICFR & 0.191 & 0.001 & $* * *$ & 0.191 & 0.002 & $* * *$ & 0.191 & 0.008 & $* * *$ & 0.191 & 0.010 & $* *$ & 0.191 & 0.049 & $* *$ \\
\hline ICWEAK & 0.304 & 0.000 & $* * *$ & 0.304 & 0.000 & $* * *$ & 0.304 & 0.000 & $* * *$ & 0.304 & 0.001 & $* * *$ & 0.304 & 0.008 & $* * *$ \\
\hline BIGN & 0.170 & 0.000 & $* * *$ & 0.170 & 0.000 & $* * *$ & 0.170 & 0.002 & $* * *$ & 0.170 & 0.003 & $* * *$ & 0.170 & 0.022 & $* *$ \\
\hline USAUDITOR & 0.430 & 0.000 & $* * *$ & 0.430 & 0.000 & $* * *$ & 0.430 & 0.000 & $* * *$ & 0.430 & 0.000 & $* * *$ & 0.430 & 0.000 & $* * *$ \\
\hline LGDP & 0.218 & 0.000 & $* * *$ & 0.407 & 0.000 & $* * *$ & 0.316 & 0.000 & $* * *$ & 0.358 & 0.000 & $* * *$ & 0.753 & 0.000 & $* * *$ \\
\hline Adj R-Sq & 0.673 & & & 0.656 & & & 0.585 & & & 0.571 & & & 0.436 & & \\
\hline Obs. & 5808 & & & 5808 & & & 5808 & & & 5808 & & & 5808 & & \\
\hline
\end{tabular}




\section{Table 7 The Effects of Higher Shareholder Rights and Excess Cash Holdings for Firms Cross-Listed in the US}

This table shows the test of hypothesis 5 using regression results for Equation 5 with dependent variable, LnFee, the natural log of audit fees. The sample is 5,808 foreign incorporated firms traded publicly in the US between 2000 and 2016. The regression is estimated using 2SLS methodology. Instruments are Civ_Com (equal to 1 for Civil, 0 for Common law), LGDP (natural log of GDP per capita in the home country), and ADRFirm (equal to 1 if the firm has an ADR ratio greater than zero). Fixed effects are included for years and Fama French industries. Significance is indicated at $99^{\text {th }}, 95^{\text {th }}$ and $90^{\text {th }}$ percentile with $* * *, * *$ and $*$, respectively.

\begin{tabular}{|c|c|c|c|c|c|c|c|c|c|c|c|c|}
\hline \multirow[b]{2}{*}{ Variable } & \multicolumn{3}{|c|}{$\begin{array}{l}\text { MODEL 1 } \\
\text { ANTIDIR }\end{array}$} & \multicolumn{3}{|c|}{$\begin{array}{c}\text { MODEL 2 } \\
\text { 1SHARE_1VOTE }\end{array}$} & \multicolumn{3}{|c|}{$\begin{array}{l}\text { MODEL } 3 \\
\text { XCONST }\end{array}$} & \multicolumn{3}{|c|}{$\begin{array}{l}\text { MODEL } 4 \\
\text { SH_Score }\end{array}$} \\
\hline & Est. & $p-v a$ & & Est. & $p$-val & & Est. & p-valt & & Est. & $p$-vall & \\
\hline Intercept & 5.390 & 0.000 & **** & 11.787 & 0.000 & **** & 6.492 & 0.000 & $* * *$ & 4.704 & 0.000 & $* * *$ \\
\hline XSCASH & 0.051 & 0.000 & $* * *$ & 0.051 & 0.051 & $*$ & 0.051 & 0.000 & $* * *$ & 0.051 & 0.013 & $* *$ \\
\hline ANTIDIR & 0.026 & 0.178 & & & & & & & & & & \\
\hline ANTIDIRXCASH & 0.085 & 0.000 & $* * *$ & & & & & & & & & \\
\hline 1SHARE_1VOTE & & & & -13.825 & 0.010 & $* * *$ & & & & & & \\
\hline 1SHARE_1VOTE XCASH & & & & 9.089 & 0.006 & $* * *$ & & & & & & \\
\hline XCONST & & & & & & & 0.238 & 0.000 & $* * *$ & & & \\
\hline XCONSTXCASH & & & & & & & 0.057 & 0.000 & $* * *$ & & & \\
\hline MGR & & & & & & & & & & -1.664 & 0.000 & $* * *$ \\
\hline MGRXCASH & & & & & & & & & & 1.631 & 0.000 & $* * *$ \\
\hline LNTA & 0.530 & 0.000 & $* * * *$ & 0.530 & 0.000 & $* * *$ & 0.530 & 0.000 & $* * *$ & 0.530 & 0.000 & $* * *$ \\
\hline INVREC & 0.934 & 0.000 & $* * *$ & 0.934 & 0.005 & $* * *$ & 0.934 & 0.000 & $* * *$ & 0.934 & 0.000 & $* * *$ \\
\hline FOREIGN & 0.032 & 0.279 & & 0.032 & 0.737 & & 0.032 & 0.295 & & 0.032 & 0.667 & \\
\hline MA & 0.140 & 0.000 & $* * *$ & 0.140 & 0.109 & & 0.140 & 0.000 & $* * *$ & 0.140 & 0.040 & $* *$ \\
\hline QRATIO & -0.041 & 0.000 & $* * *$ & -0.041 & 0.086 & * & -0.041 & 0.000 & $* * *$ & -0.041 & 0.028 & $* *$ \\
\hline $\mathrm{ROA}$ & -0.263 & 0.000 & $* * *$ & -0.263 & 0.117 & & -0.263 & 0.000 & $* * *$ & -0.263 & 0.045 & $* *$ \\
\hline LOSS & 0.081 & 0.012 & $* *$ & 0.081 & 0.433 & & 0.081 & 0.015 & $* *$ & 0.081 & 0.315 & \\
\hline LEV & 0.055 & 0.256 & & 0.055 & 0.724 & & 0.055 & 0.272 & & 0.055 & 0.651 & \\
\hline GROWTH & -0.037 & 0.004 & $* * *$ & -0.037 & 0.366 & & -0.037 & 0.005 & $* * *$ & -0.037 & 0.247 & \\
\hline MTB & 0.008 & 0.006 & $* * *$ & 0.008 & 0.393 & & 0.008 & 0.008 & $* * *$ & 0.008 & 0.275 & \\
\hline RESTATE & 0.032 & 0.556 & & 0.032 & 0.855 & & 0.032 & 0.569 & & 0.032 & 0.815 & \\
\hline XDOPS & 0.206 & 0.000 & $* * *$ & 0.206 & 0.059 & $*$ & 0.206 & 0.000 & $* * *$ & 0.206 & 0.016 & $* *$ \\
\hline BUSY & -0.135 & 0.000 & $* * *$ & -0.135 & 0.163 & & -0.135 & 0.000 & $* * *$ & -0.135 & 0.074 & $*$ \\
\hline INITIAL & -0.141 & 0.000 & $* * *$ & -0.141 & 0.258 & & -0.141 & 0.000 & $* * *$ & -0.141 & 0.148 & \\
\hline $\mathrm{GC}$ & 0.131 & 0.029 & $* *$ & 0.131 & 0.497 & & 0.131 & 0.035 & $* *$ & 0.131 & 0.385 & \\
\hline ICFR & 0.191 & 0.000 & $* * *$ & 0.191 & 0.232 & & 0.191 & 0.000 & $* * *$ & 0.191 & 0.126 & \\
\hline ICWEAK & 0.304 & 0.000 & $* * *$ & 0.304 & 0.109 & & 0.304 & 0.000 & $* * *$ & 0.304 & 0.040 & $* *$ \\
\hline BIGN & 0.170 & 0.000 & $* * *$ & 0.170 & 0.164 & & 0.170 & 0.000 & $* * *$ & 0.170 & 0.075 & $*$ \\
\hline USAUDITOR & 0.430 & 0.000 & $* * *$ & 0.430 & 0.001 & $* * *$ & 0.430 & 0.000 & $* * *$ & 0.430 & 0.000 & $* * *$ \\
\hline
\end{tabular}


LGDP

Adj R-Sq

Obs.
$0.358 \quad 0.000^{* * *}$

0.750

5,808
$-0.243$

0.317

0.218

5,808

$\begin{array}{llll}0.104 & 0.0433^{* *} & 0.516 \\ & & & \\ 0.737 & & & 0.317 \\ 5,808 & & & 5,808\end{array}$

